\title{
Patient-centered care interventions to reduce the inappropriate prescription and use of benzodiazepines and z- drugs: a systematic review
}

\begin{abstract}
Aliaksandra Mokhar ${ }^{\text {Corresp., }}{ }^{1}$, Janine Topp ${ }^{2}$, Martin Härter ${ }^{1}$, Holger Schulz $^{1}$, Silke Kuhn ${ }^{3}$, Uwe Verthein ${ }^{3}$, Jörg Dirmaier ${ }^{1}$

1 Department of Medical Psychology, University Medical Center Hamburg-Eppendorf, Hamburg, Germany

2 Department of Health Services Research in Dermatology and Nursing, University Medical Center Hamburg-Eppendorf, Hamburg, Germany

3 Department of Psychiatry and Psychotherapy, Center for Interdisciplinary Addiction Research, University Medical Center Hamburg-Eppendorf, Hamburg, Germany

Corresponding Author: Aliaksandra Mokhar

Email address: a.mokhar@uke.de
\end{abstract}

Background: Benzodiazepines (BZDs) and z-drugs are effective drugs, but they are prescribed excessively worldwide. International guidelines recommend a maximum treatment duration of four weeks. Although these drugs are effective in the short term, long-term BZD therapy is associated with considerable adverse effects, the development of tolerance, and, finally, addiction. However, there are different interventions in terms of patient-centered care that aim to reduce the use of BZDs and z-drugs as well as assist health care professionals (HCPs) in preventing the inappropriate prescription of BZDs. Aim: The aim of this systematic review was to identify interventions that promote patientcentered treatments for inappropriate BZD and z-drug use and to analyze their effectiveness in reducing the inappropriate use of these drugs. Methods: To identify relevant studies, the PubMed, EMBASE, PsycINFO, Psyndex and Cochrane Library databases were searched. Studies with controlled designs focusing on adult patients were included. Trials with chronically or mentally ill patients were excluded if long-term BZD and z-drug use was indicated. Study extraction was performed based on the Cochrane Form for study extraction. To assess the quality of the studies, we used a tool based on the Cochrane Collaboration's tool for assessing the risk of bias in randomized trials. Results: We identified 7068 studies and selected 20 for systematic review. Nine interventions focused on patients, nine on HCPs, and two on both patients and HCPs. Intervention types ranged from simple to multifaceted. Patient-centered interventions that provided patient information effectively increased the appropriate use of BZDs. The educational approaches for HCPs that aimed to achieve appropriate prescription reported inconsistent results. The methods that combined informing patients and HCPs led to a significant reduction in BZD use. Conclusions: This is the first review of studies focused on patient-centered 
approaches to reducing the inappropriate prescription and use of BZDs and z-drugs. The patient-centered dimension of patient information was responsible for a decrease in BZD and z-drug consumption. Further, in some studies, the patient-centered dimensions responsible for reducing the prescription and use of BZDs and z-drugs were the clinician's essential characteristics and clinician-patient communication. 
Patient-centered care interventions to reduce the inappropriate prescription and use of benzodiazepines and z-drugs: a systematic review

Aliaksandra Mokhar ${ }^{1}$, Janine Topp², Martin Härter ${ }^{1}$, Holger Schulz ${ }^{1}$, Silke Kuhn ${ }^{3}$, Uwe Verthein ${ }^{3}$, Jörg Dirmaier $^{1}$

6

7

$8 \quad{ }^{1}$ Department of Medical Psychology

9 University Medical Center Hamburg-Eppendorf

10 Martinistr. 52

1120246 Hamburg

12 Germany

${ }^{2}$ Department of Health Services Research in Dermatology and Nursing

16 Hamburg Center for Health Economics

17 University Medical Center Hamburg-Eppendorf

18 Martinistraße 52

1920246 Hamburg

20 Germany

21

${ }^{3}$ Center for Interdisciplinary Addiction Research

23 Department of Psychiatry and Psychotherapy

24 University Medical Center Hamburg-Eppendorf

2520246 Hamburg

26 Germany

27

Correspondence should be addressed to:

32 Aliaksandra Mokhar

Department of Medical Psychology

34 University Medical Center Hamburg-Eppendorf

35 Martinistr. 52, 20246 Hamburg Germany

36 Tel. +49 (0) 15222895576

37 Fax +49 (0) $407410-58170$

38 E-mail: a.mokhar@uke.de 


\section{Abstract}

40

41

42

43

Background: Benzodiazepines (BZDs) and z-drugs are effective drugs, but they are prescribed excessively worldwide. International guidelines recommend a maximum treatment duration of four weeks. Although these drugs are effective in the short term, long-term BZD therapy is associated with considerable adverse effects, the development of tolerance, and, finally, addiction. However, there are different interventions in terms of patient-centered care that aim to reduce the use of BZDs and z-drugs as well as assist health care professionals (HCPs) in preventing the inappropriate prescription of BZDs.

Aim: The aim of this systematic review was to identify interventions that promote patient-centered treatments for inappropriate BZD and z-drug use and to analyze their effectiveness in reducing the inappropriate use of these drugs.

Methods: To identify relevant studies, the PubMed, EMBASE, PsycINFO, Psyndex and Cochrane Library databases were searched. Studies with controlled designs focusing on adult patients were included. Trials with chronically or mentally ill patients were excluded if long-term BZD and z-drug use was indicated. Study extraction was performed based on the Cochrane Form for study extraction. To assess the quality of the studies, we used a tool based on the Cochrane Collaboration's tool for assessing the risk of bias in randomized trials.

Results: We identified 7068 studies and selected 20 for systematic review. Nine interventions focused on patients, nine on HCPs, and two on both patients and HCPs. Intervention types ranged from simple to multifaceted. Patient-centered interventions that provided patient information effectively increased the appropriate use of BZDs. The educational approaches for HCPs that aimed to achieve appropriate prescription reported inconsistent results. The methods that combined informing patients and HCPs led to a significant reduction in BZD use.

Conclusions: This is the first review of studies focused on patient-centered approaches to reducing the inappropriate prescription and use of BZDs and z-drugs. The patient-centered dimension of patient information was responsible for a decrease in BZD and z-drug consumption. Further, in some studies, the patient-centered dimensions responsible for reducing the prescription and use of BZDs and z-drugs were the clinician's essential characteristics and clinician-patient communication. 


\section{Introduction}

Benzodiazepines (BZDs) and z-drugs (BZD derivatives, e.g., zolpidem and zopiclone) are among the most commonly used anxiolytics and hypnotics worldwide (Fassaert et al. 2007; Rogers et al. 2007). While BZD and z-drugs have been demonstrated to be effective in short-term use (Ottawa 2014), their intake is associated with serious adverse effects, including increased risk of cognitive impairments (Barker et al. 2004; McAndrews et al. 2003; Paterniti et al. 2002) as well as stumbling and falling, which may result in hip fractures (Takkouche et al. 2007; Zint et al. 2010) as withdrawal symptoms (Rickels et al. 1990). The main serious problem associated with long-term use is the development of tolerance and dependence (Ashton 2005; Voyer et al. 2009; Zint et al. 2010). The risks and adverse effects of BZDs are of particular relevance to older people. Therefore, the Beers Criteria Update Expert Panel for potentially inappropriate medication use recommends avoiding the prescription of BZDs to patients over the age of 65 years, regardless of their primary disease or symptoms (American Geriatrics Society Beers Criteria Update Expert 2012). Although guidelines and expert consensus confirm the risks associated with the long-term use of BZD, these drugs are still prescribed frequently (Fassaert et al. 2007; Rogers et al. 2007). Thus, despite increasing awareness of the associated risks, the prevalence of inappropriate use has not declined (Cunningham et al. 2010; Huerta et al. 2015).

"Inappropriate" BZD use is defined as BZD use that is associated with a significantly higher risk of adverse effects than treatment with an alternative evidence-based intervention that is equally, if not more, effective (Beers \& Ouslander 1989; Opondo et al. 2012). Different motives have been given for the inappropriate use of BZDs. Patients report that they lack information on alternative pharmacological and nonpharmacological treatment options, the discontinuation of BZDs, and the potentially hazardous effects of inappropriate BZD use $(16,17)$. Furthermore, regarding the patients perspective, they are often unwilling to discontinue BZD use, as possible physiological and psychological dependencies might be present (Fang et al. 2009; Tannenbaum et al. 2014). Different reasons for the inappropriate prescription of BZDs have been assessed (Anthierens et al. 2007b; Opondo et al. 2012; Voyer et al. 2009). These reasons include lack of knowledge of possible evidence-based alternative treatment options, nonspecific knowledge about BZDs among physicians and other specialists, especially in geriatric care, a lack of clarity about how to appropriately prescribe the drug and difficulties applying medication guidelines to clinical practice (Ashton 2005; Opondo et al. 2012). Although physicians report being cautious about initiating BZD treatments, the psychosocial problems of patients are often severe, and the knowledge of how to handle these severe problems using alternative strategies is often limited (Anthierens et al. 2007a; Parr et al. 2006). Given the variety of severe risks and adverse effects, including possible dependency, the high prevalence of BZD use in older people in general and the high number of long-term users in particular, interventions that address this issue need to be identified (Gould et al. 2014; Oude Voshaar et al. 2006; Smith \& Tett 2010). To address this need, numerous studies have focused on the difficulties in physician-patient communication and patient information involved in the inappropriate use and prescription of BZDs. These studies have investigated specific interventions that are designed to educate patients, provide patient information material, improve physician-patient communication, or build a relationship between patients and physicians (Gould et al. 2014; Mugunthan et al. 2011). These interventions can be considered to fall under the umbrella term patient-centeredness (Scholl et al. 2014; Zill et al. 2015). Patient-centered care is a comprehensive care concept (25). Various definitions have tried to encompass the complexity of this idea (26-28). Recently, Scholl and colleagues (28) merged existing definitions and developed a comprehensive model of patient-centeredness. These researchers 
defined 15 dimensions of patient-centeredness and, according to expert consensus, isolated the five most relevant dimensions (Scholl et al. 2014). In addition to being treated as a unique individual, the patient's involvement in his or her own care, patient empowerment, patient information and clinician-patient communication were rated as the most relevant aspects (Zill et al. 2015). The latter dimensions are mainly understood to be the activities of patient-centered care, which has become an international demand for high-quality medicine (Mead \& Bower 2000; Phelan et al. 2001).

An increased emphasis on patient-centeredness could address the causes of inappropriate BZD use and decrease its prevalence by focusing on patients' values. Patients' beliefs, preferences and information need to play a greater role in the care process. Putting the individual patient rather than his or her disease at the center of the treatment plan has increasingly been advocated, and numerous medical experts recommend the implementation of this strategy in routine care (Committee on Quality of Health Care in America 2001). Research in various sectors of health care attests to improved care processes as a result of patient-centered approaches. Patients have reported that such approaches restored their satisfaction and self-management abilities and significantly improved their quality of life (Rathert et al. 2012).

Research of the physician's perspective describes the need for professional expertise, specific communication skills and the ability to inform patients based on the evidence-based knowledge presented in guidelines and expert consensuses for clinical practice. Some studies have found that good physicianpatient communication is associated with important patient health outcomes (Mercer et al. 2008; Zolnierek \& Dimatteo 2009). In addition to dimensions regarding physicians' abilities, there are communication factors related to patient-centered activities where physicians provide information and better educate patients by sharing specific information and using informational resources and tools (Scholl et al. 2014). Furthermore, recent research indicates that interventions that promote patientcentered care have a positive influence on patient-related outcomes (Dwamena et al. 2012; Mead \& Bower 2002).

The high prevalence of inappropriate BZD use and the possible reasons for this use combined with the knowledge of the general benefits of a patient-centered approach in health care highlight the need to consider a patient-centered approach for patients using BZDs. By focusing on the five most important aspects of patient-centered care, this systematic review aimed to identify patient-centered interventions for reducing the inappropriate prescription and use of BZDs and z-drugs.

\section{Methods}

This systematic review was registered with the International Prospective Register of Systematic Reviews (PROSPERO): CRD42014015616. The reporting guidelines used for this review were based on the Preferred Reporting Items for Systematic Reviews and Meta-Analyses (PRISMA) statement (Liberati et al. 2009; Moher et al. 2009). A study protocol was not published.

\section{Search strategy}

A search was performed using the following databases: Medline (via Ovid), EMBASE, PsycINFO, Psyndex and the Cochrane Library. The following search terms were used: benzodiazepine(s) and/or z$\operatorname{drug}(\mathrm{s})$ and/or anxiolyt*, hypnotic* in combination with information*, communicat*, educat*, support*, 
system*, aid*, program*, process*, material*, health intervent*, shared decision*, informed decision*, choice*, and train*. A sample syntax can be found in the appendix. The search was limited to studies published in English or German. The search began in September 2014 and was completed in October 2014.

\section{Eligibility criteria}

Studies were included in this review if they met the following criteria: had a controlled design, assessed middle-aged adults (45 years and older), used interventions focused on users of BZD or z-drugs and/or health care professionals (HCPs) involved in the care process, and had a primary outcome of interest of a reduction in BZD use and/or prescriptions. We excluded case series, review papers, meta-analyses, double publications, experimental research, protocols and animal research. Moreover, studies were excluded if they focused on children or on chronically or seriously mentally ill patients, i.e., if the use of BZDs was indicated (e.g., for severe psychiatric disorders such as schizophrenia). Psychopharmacological studies that examined medication phenomena only with respect to the drugs' effects were also excluded. The types of interventions included were predominantly educational or informational in nature.

As part of our search strategy, we also performed a secondary search consisting of reference tracking for all full-text documents included and a consultation of experts in the respective health care fields.

\section{Study selection}

First, duplicates were removed. Second, two independent researchers (AM, JT or EC) screened the selected articles, first by title and then by abstract, for interventions related to the research topic. When the title and abstract were relevant or when eligibility was uncertain, the full text was retrieved. Any uncertainty concerning eligibility was resolved after an assessment of the full text and a discussion within the research team.

\section{Data extraction and quality assessment}

The collected data were extracted using a standardized sheet we had developed previously that was based on the Cochrane Extraction Form (Cochrane). The extraction form includes information about participants' characteristics (age, gender), the treatment setting, inclusion and exclusion criteria, the randomization process, the intervention description, the duration of the intervention, outcomes, followups, results and significance. The interventions included were classified by the target population: BZD users, HCPs, or both groups. Data were extracted independently by two authors (AM and JT). Additionally, to consider the potential limitations of the studies included, the quality (or risk of bias) of these studies was assessed by two authors (AM and JT) using the Cochrane Collaboration's tool for assessing the risk of bias in randomized trials (Higgins et al. 2011). The quality assessment form was based on six dimensions: random sequence generation, allocation concealment, blinding of participants and personnel, blinding of outcome assessments, incomplete outcome data and selective reporting.

\section{Data analysis}

We used a qualitative analysis to synthesize the data extracted from the included studies (Dixon-Woods et al. 2005). Intervention approaches were classified into the following categories: those targeting patients, those with HCPs and multifaceted interventions. Furthermore, we subdivided the interventions into three 
patient-centered categories: physicians' essential characteristics, clinician-patient communication and patient information. A meta-analysis could not be conducted because the interventions were too heterogeneous.

\section{Results}

The review findings are presented in three steps. First, the studies are described and illustrated with charts. Then, they are subdivided into three sets, namely, patients, HCPs, and both groups combined. Next, the findings are described by an analysis of study quality, and then, the results are summarized in terms of patient-centered dimensions.

We identified 7068 studies through the electronic search and 11 studies through our secondary search strategy. After the removal of duplicates (4 628) and after the screening process, 20 studies remained relevant and met the inclusion criteria (see fig. 1).

\section{Description of identified studies}

All studies were published in English between 1992 and 2014. The interventions were conducted in the United Kingdom (four studies), Australia (four studies), the USA (two studies), the Netherlands (two studies), Canada (two studies), Spain (three studies), Ireland (one study), Belgium (one study) and Sweden (one study). All studies were based on at least a controlled design. Eight studies used an explicit randomized controlled design, an additional nine used a controlled design (including intervention studies), and four used a cluster-randomized design. The study durations varied between four weeks and twentyone months, with a mean of six months. Furthermore, the studies were conducted in different clinical settings that targeted inpatients, outpatients, community residents, or nursing home residents. The majority of the studies were conducted in general practices (eleven studies) and nursing homes (five studies). One study each was carried out in a medical center, a hospital, an outpatient service (Medicaid), and a community pharmacy. While nine studies directly addressed BZD users (long-term, chronic, inappropriate), nine studies focused only on HCPs, specifically general practitioners and nurses. Two studies investigated the effect of interventions on both target patients and HCPs (physicians, nurses and pharmacists). A systematic overview of relevant information for all interventions is shown in tables 1-3.

\section{Quality assessments}

The studies included in this survey differed considerably with respect to methodological quality (Higgins et al. 2011). Detailed evaluations for all studies are included in table 4. Three categories were used to describe assessment quality: low, high and unclear risk of bias ("yes" signified low risk; "no", high risk; and "unclear", all other cases). In a second step, quantitative levels were introduced; to meet the "low risk" level, all items in the question were required to have a low risk of bias. The "high risk" and "unclear" levels needed one item with a high risk of bias or an unclear risk of bias, respectively. 
222 Regarding randomization, six studies were excluded from the assessment because of their study design (controlled trial) (Bashir et al. 1994; Cormack et al. 1994; Smith \& Tett 2010; Stewart et al. 2007; Westbury et al. 2010). In the remaining studies, the randomization was described clearly. Regarding allocation, six studies described in detail an allocation that was performed successfully (Cormack et al. 1994; Patterson et al. 2010; Tannenbaum et al. 2014; Ten Wolde et al. 2008; Vicens et al. 2014; Vicens et al. 2006). Four studies reported an inappropriate allocation (Bashir et al. 1994; Gorgels et al. 2005; Stewart et al. 2007; Westbury et al. 2010). In the remaining studies, the allocation was unclear. Regarding the blinding of participants, only two studies performed this procedure adequately (Pimott et al. 2003; Tannenbaum et al. 2014). Two other studies poorly described how the blinding process was carried out (Avorn et al. 1992; Ten Wolde et al. 2008). The remaining seventeen studies did not undertake any blinding of participants. Regarding the blinding of outcomes, six studies clearly blinded outcomes and documented the process well (Heather et al. 2004; Pimott et al. 2003; Pit et al. 2007; Stewart et al. 2007; Tannenbaum et al. 2014; Vicens et al. 2014), two studies examined the outcomes in a nonblinded manner (Batty et al. 2001; Smith et al. 1998), and in the remaining twelve studies, it was unclear whether the respective outcomes had been blinded. The careful blinding in most studies may have impacted their results. Regarding incomplete outcome data, six studies were considered satisfactory, with a low probable risk of bias (Bashir et al. 1994; Gorgels et al. 2005; Tannenbaum et al. 2014; Vicens et al. 2014; Vicens et al. 2006). In seven additional studies, outcome data were considered incomplete, increasing the risk of bias (Avorn et al. 1992; Heather et al. 2004; Pit et al. 2007; Roberts et al. 2001; Smith \& Tett 2010; Smith et al. 1998; Ten Wolde et al. 2008). Due to insufficient information, it could not be determined whether all patients in the remaining studies were included in the respective analyses; therefore, the risk of bias was unclear. Regarding selective reporting, only one study was found to have a low risk of bias (Tannenbaum et al. 2014). For the remaining studies, it was unclear whether important outcomes had not been produced or had simply not been reported.

In general, study quality was affected by a high risk of bias. Of the twenty-one studies in question, only one met all six categories to show no risk of bias (Tannenbaum et al. 2014). Seven studies were identified as having a low risk of bias in half of the categories, particularly those dealing with randomization and allocation and, to a lesser extent, the blinding of outcomes (Heather et al. 2004; Patterson et al. 2010; Pimott et al. 2003; Roberts et al. 2001; Tannenbaum et al. 2014; Vicens et al. 2014). However, in these studies, the presentation of selective reporting was poor. The remaining 15 studies had a high risk of bias, mainly in the blinding of patients and personnel category. These studies also had poor presentations with respect to the blinding of outcomes and to incomplete data. Although most studies performed randomization well, a high risk of bias was prevalent in all five remaining categories. Thus, the overall quality of these studies, ranging from average to low, needs to be considered when interpreting their results. For the remaining valuation categories, all studies revealed vastly different standards of quality and poor presentation of procedures. If personnel and patients were not blinded, if the measurement processes became apparent, or if the results were not presented properly and completely, the effectiveness of the study in question could be compromised.

\section{Summary of findings}

The study results are presented again in terms of group subdivisions (patients, HCPs, both groups combined) and dimensions of patient-centered care. The data analysis identified three dimensions within 
263

264

265

266

267

268

269

270

271

272

273

274

275

276

277

278

279

280

281

282

283

284

285

286

287

288

289

290

291

292

293

294

295

296

297

298

299

300

301

302

the model of patient-centered care: patient information, clinician-patient communication, and essential characteristics of the clinician (Scholl et al. 2014).

\section{Interventions concerning patients}

Nine studies focused on patient interventions. Five studies examined the impact of patient information on the reduction of BZD use (Bashir et al. 1994; Cormack et al. 1994; Gorgels et al. 2005; Tannenbaum et al. 2014; Ten Wolde et al. 2008), while the remaining four studies looked at a combination of patient information and extra clinician-patient communication (Heather et al. 2004; Stewart et al. 2007; Vicens et al. 2014; Vicens et al. 2006).

\section{Patient information}

Bachir et al. (1994) demonstrated a short and simple intervention in which general advice from the GP combined with a self-help booklet reduced BZD intake after six months among patients who had taken the medication for more than a year (Bashir et al. 1994). In a randomized controlled trial (RCT), Cormack and colleagues (1994) suggested that a letter containing information on BZDs and advice on how to reduce their intake, followed by 4 monthly information sheets, could reduce the intake of BZDs by approximately 1/3 after 6 months (Cormack et al. 1994). According to the authors, this simple method could significantly decrease intake among older people as well, whereas previous research suggested that such a reduction was harder to achieve. Another RCT with more than 4000 participants showed that a letter with advice on how to gradually discontinue BZD use, followed by an appointment with the family practitioner to evaluate actual drug use, could significantly reduce participants' BZD intake. A follow-up after twenty one months confirmed the effectiveness of this intervention (Gorgels et al. 2005). In a subsequent RCT, Tannenbaum and colleagues (2014) suggested that a personalized eight-page patientempowerment booklet, based on social constructivist learning and self-efficacy theory, supported the complete cessation of BZD use in older people. An overall reduction in BZD intake was observed 6 months after the intervention (Tannenbaum et al. 2014). Individually tailored interventions delivered to patients either once or three times in a row were effective at discontinuing BZD intake. Moreover, scientists from the Netherlands compared these tailored interventions to a short letter from a general practitioner and found that the former was superior (Ten Wolde et al. 2008).

\section{Patient information and clinician-patient communication}

Stewart and colleagues (2007) showed that a letter from a GP with a request to stop or reduce BZD use with their help coupled with a reminder six months later for those who had not responded significantly reduced the number of prescriptions per patient per half year. Nearly 150 practices and more than 8000 patients were included in this study (Stewart et al. 2007). Heather et al. (2004) demonstrated how the dissemination of information to patients along with auxiliary educational talks with a GP could lead to a reduction in BZD intake within twelve months (Heather et al. 2004). BZD intake among older patients could be reduced in two ways: via patient information only or via patient information plus supportive communication from a physician. There was no significant difference between the first intervention with information on BZD provided by the GP (combined with a talk) and a second intervention consisting only of a letter signed by the GP. However, significant differences were found in a study that compared routine clinical practice to a treatment that contained standardized advice as well as a tapering-off schedule and biweekly follow-up visits (Vicens et al. 2006). At the twelve-month follow-up, $45 \%$ of patients in the 
intervention group and 9.1\% in the control group had discontinued their BZD use. This study concluded that the intervention was effective in terms of reducing long-term BZD use and was feasible in primary care. Vincens and colleagues (2014) conducted workshops that trained physicians how to interview patients and how to individualize patient information to lead to a gradual tapering of patients' BZD intake. Regardless of whether patient consultations were followed by additional visits or written instructions, there was a reduction in long-term BZD use in patients without severe comorbidities (Vicens et al. 2014).

\section{Interventions for health care professionals}

Next, we systematically analyzed the studies that employed interventions aimed at HCPs and focused on their essential characteristics and clinician-patient communication as part of the patient-centered care model.

\section{Essential characteristics of the clinician}

Berings and colleagues (1994) conducted a study to assess whether oral and written information on BZDs or written information alone would have an effect on industry-independent information related to BZD prescribing among general practitioners. The statistical analysis suggested that the combination of physician contact and written information (24\%) was superior to only written information (14\%); both interventions together led to a decrease in the prescribing rate (Berings et al. 1994). Midlöv et al. (2006) examined the effect of outreach visits. Experts visited physicians at private practices twice and provided them with information on confusion in older people and the effects of BZDs as well as other psychotropic drugs on this population (Midlov et al. 2006). One year after the intervention, researchers found a significant decrease $(25.8 \%)$ in the number of prescriptions of BZD. Pimlott and colleagues (2003) were interested in the effects of regular emails sent to physicians over a six-month period with two-month intervals. The email contained confidential profiles of BZD prescription users and educational bulletins (Pimott et al. 2003). Physicians in the control group received educational bulletins related to antihypertension drug prescriptions for older people. The researchers reported a $0.7 \%$ decrease in prescribing rates in the intervention group and a $1.1 \%$ increase in the control group, but this difference was not significant. An educational program developed by Pit et al. (2007) evaluated an intervention complex that consisted of three major parts: educational resources (academic detailing, prescribing information and feedback), medication risk assessments, and a medication review checklist (Pit et al. 2007). However, the intervention group did not show a significant reduction in the use of BZDs $(\mathrm{OR}=0.51 ; 95 \%)$. Roberts et al. (2001) designed an approach to improve the quality of medication care among nursing home residents at large (Roberts et al. 2001). This intervention consisted of three phases: the introduction to stakeholders of a new professional role related to relationship building, the education of nurses, and a medication review by pharmacists with a postgraduate diploma in clinical pharmacology. While the authors did not find a substantial change in morbidity indices or survival rates (primary outcomes), they did detect a significant decrease of $16.6 \%$ in BZD intake (14.8\% in cumulative drug intake). Smith and colleagues (1998) investigated the effect of an intervention packet mailed to prescribers of BZDs (Smith et al. 1998). This package consisted of an intervention letter, a review of drug use, guidelines and a prescriber-specific profile about the prescription of sedative hypnotics, as well as a patient profile for each of the prescriber's patients who were identified as overutilizers. The researchers 
344

345

346

347

348

349

350

351

352

353

354

355

356

357

358

359

360

361

362

363

364

365

366

367

368

369

370

371

372

373

374

375

376

377

378

379

380

381

382

determined that this intervention significantly reduced the use of BZDs as a targeted sedative hypnotic medication in the intervention group (27.6\%) versus a control group (8.5\%). Smith and Tett (2010) investigated whether informing HCPs about BZD intake via emails and a website affected the number of BZD prescriptions over a 6-month period (Smith \& Tett 2010). After the intervention, there was a significantly smaller number of aged care residents who had used BZDs for 6 months or more $(\mathrm{P}<0.05)$ but no significant change in the number of residents taking BZDs or taking BZDs for a long time and no significant change in the quantitative use of BZDs compared to the use among two different control areas (groups).

Essential characteristics of the clinician and clinician-patient communication

Avorn and colleagues (1992) found a significant reduction in the use of psychoactive drugs (BZD included) among residents at three nursing homes after they implemented a comprehensive educational outreach program ("academic detailing") for HCPs (Avorn et al. 1992). The reduction in BZD intake was $20 \%$ in the intervention group and $9 \%$ in the control group, and the patients in the intervention group reported reduced anxiety but more memory loss than the control group. Batty et al. (2001) investigated whether an interactive lecture or the dissemination of printed materials to physicians, nurses and pharmacists would change the prescribing rate of BZDs towards a more appropriate rate for inpatients (Batty et al. 2001). Nearly 1500 inpatients were included in the study. The prescribing rates were handled more appropriately in both intervention groups (intervention group 1: $29 \%$ to $44 \%$; intervention group 2 : $42 \%$ to $33 \%$ ) than in a control group (42-42\%), but these differences were not significant.

\section{Interventions for patients and health care professionals}

Finally, we identified two studies that employed a multifaceted approach towards both patients and HCPs that involved several dimensions of the patient-centered care model.

Essential characteristics of the clinician, clinician-patient communication, and patient information

Patterson et al. (2010) developed a multifaceted approach that entailed medication reviews by pharmacists over a twelve-month period (Patterson et al. 2010). The pharmacists' visits consisted of a review of the residents' prescribing information, the use of an algorithm to help prescribers assess the appropriateness of a medication, and individual conversations on improving prescriptions. As a result of the intervention, the proportion of residents taking inappropriate psychoactive medications at 12 months in the intervention group $(25 / 128,19.5 \%)$ was significantly lower $(\mathrm{P}<.001)$ than that in the control group $(62 / 124,50.0 \%)$ (odds ratio 50.26, 95\% confidence interval 0.14-0.49) after adjustment for clustering within homes. No differences were observed at 12 months in the fall rate between the intervention group and the control group. Finally, these visits led to significantly lower rates of BZD prescribing and intake in the intervention group. In an RCT, Westbury et al. (2010) utilized a strategy from the Reducing Use of Sedatives (RedUSE) project (Westbury et al. 2010). This project involved a multistrategic interdisciplinary intervention for reducing the inappropriate use and promoting the appropriate use of medications that entails educational sessions, academic detailing and a targeted sedative review. The intervention included raising awareness, two drug use evaluation (DUE) cycles, educational sessions, promotional materials (newsletters, pamphlets, posters), academic detailing, and a targeted sedative 
review. This intervention complex led to a significant reduction in intervention home residents regularly taking benzodiazepines $(31.8 \%$ to $26.9 \%, \mathrm{p}<0.005)$ and antipsychotics $(20.3 \%$ to $18.6 \%, \mathrm{p}<0.05)$; there were significantly more dose reductions and cessations in intervention homes than in control homes (BDZ: $39.6 \%$ vs. $17.6 \%, p<0.0001$; antipsychotics: $36.9 \%$ vs. $20.9 \%, p<0.01$ ) for residents taking benzodiazepines and antipsychotics at baseline. In summary, the intervention of von Westbury and colleagues led to a significantly higher rate of dosage reductions or cessations in intervention homes than in control homes.

\section{Discussion}

This review surveyed twenty-one interventions aimed at reducing the inappropriate prescription or use of BZDs and z-drugs. All interventions were based on patient-centered dimensions: patient information, clinician-patient communication, and essential characteristics of the clinician. We used the description of the interventions to assign them to the respective three dimensions of the patient-centered care model developed by Scholl and colleagues (Scholl et al. 2014). Patient-centered care is a broad concept in health care; this review shows that although there has been a growing focus on interventions that reduce the inappropriate use of BZDs and z-drugs, no study was defined as a patient-centered intervention or specifically measured the effects of such an intervention. Importantly, all included studies used a controlled design, and most showed a positive effect on the inappropriate prescription and use of BZDs and z-drugs for the intervention compared with typical care. There were comparisons between interventions and typical care as well as between interventions and other interventions. The interventions focused on patients showed a greater effect than those focused on HCPs. The studies that included both groups also showed a positive effect. This review suggests that patient-centered interventions that actively target patients, health professionals, or both are better than no intervention at all. Based on the results of this work, the following recommendations can be derived.

First, studies that examined patient information as one important dimension of patient-centered care and focused exclusively on patient-targeted interventions did not indicate a specific way to successfully reduce BZD and z-drug intake. In contrast, it has been shown that there are many methods to provide information that consider the patient's informational needs and preferences. Studies have demonstrated that most educational interventions are more effective with middle-aged participants than with older participants (Mead \& Bower 2002; Meador et al. 1997). However, studies assessing elderly people show more diverse results than those without any age specifications (Mercer et al. 2008); therefore, there is a high probability that the effects of these interventions can also be achieved in older populations. The patient information studies established that providing patients (regardless of age) with information effectively led to the reduction or discontinuation of BZD and z-drug use, and this finding is consistent with previous research (Mugunthan et al. 2011; Voshaar et al. 2006). Providing facts in a comprehensive and well-arranged way, as patient information does, encourages patients to consider reducing or discontinuing the use of the drug (Bodenheimer et al. 2002). Among the interventions that targeted patients, two studies supplemented the provision of patient information through consultations and active support by personnel; these studies also showed a significant reduction in BZD use. Providing patient information encourages patients to discuss these topics with their physician (Harter et al. 2011; Oshima Lee \& Emanuel 2013). Advising patients and discussing the best possible treatments are the main 
424

425

426

427

428

429

430

431

432

433

434

435

436

437

438

439

440

441

442

443

444

445

446

447

448

449

450

451

452

453

454

455

456

457

458

459

460

461

462

463

464

465

purposes of patient-centered care (Epstein 2000; Scholl et al. 2014). The findings here emphasize the importance of providing patient information as part of a patient-centered approach (Farmer et al. 2008; Zill et al. 2015).

Second, the majority of the studies that focused on clinician-patient communication and essential characteristics of the clinician (HCPs) investigated interventions for HCPs; only three studies investigated interventions for patients. Studies that focused on patient interventions assessed a combination of patient information and clinician-patient communication and suggested that direct educational interventions and discussions with HCPs effectively reduces or stops inappropriate BZD use. This finding can be explained by the active participation of patients in the care process, as they are provided with all the information they need to make decisions regarding their medication consumption. Interventions targeting HCPs that include a combination of patient information sources (via e-mail, letter) and follow-up personal contact with HCPs provide models of success that may be more likely to be effective in reducing the inappropriate prescription and use of BZDs and z-drugs. This two-way communication is an important method of building practitioner-specific skills and increasing practitioner involvement in the interaction (Rao et al. 2007). Although we did not explicitly describe and analyze secondary outcomes, in some of these combined studies, the most important results were the absence of symptoms (anxiety, distress, behavior disorders, life quality) as BZD usage was reduced (Avorn et al. 1992). The results were more varied with regard to interventions that concentrated on a set of verbal and nonverbal communication opportunities and skills and a set of attitudes, including those towards the patients, the HCPs themselves (self-reflection) and the medical competency of the HCPs. While some studies have found that the sole use of informative and educational training with printed educational material, training sessions and/or expert visits had positive effects on prescription rates and/or BZD use, other studies did not find similar results. However, it is possible that with educational efforts, positive changes with respect to the inappropriate prescription and consumption of BZDs can be achieved without disrupting care routines or producing high economic costs (Grimshaw et al. 2001). The factors associated with the knowledge and skills of prescribers belong to the most important dimension of patient-centered care. However, there are no conclusions concerning the comparison of effects between the significant studies. Most studies with statistically significant results used interventions that consisted of complex designs and methods, such as combinations of education and active individual exchanges about prescribing practices. These results suggest that an active exchange of knowledge during discussion leads to improvements in prescription habits. The duration of the studies that targeted clinician-patient communication and the specific characteristics of HCPs ranged from five to twelve months (one study lasted four weeks), suggesting that positive effects need time but will also be long-lasting. However, some of the studies that examined communication specifications or essential characteristics of HCPs did not report significant positive changes in prescription rates or the use of BZDs. A few explanations for these findings were provided (Batty et al. 2001; Pimott et al. 2003), in particular, a focus on only one method of intervention (bulletin information) and a failure to combine several strategies. Furthermore, changes in prescribing habits associated with a long-term therapy (as with BZDs) are more difficult than in cases of acute and nonrecurring therapies, and some patients do not associate their medications with harmful effects. Therefore, more studies are needed that clearly define and describe the patient-centered dimensions of communication and HCP characteristics to allow for explicit comparisons and recommendations for clinical practice. 
466

467

468

469

470

471

472

473

474

475

476

477

478

479

480

481

482

483

484

485

486

487

488

489

490

491

492

493

494

495

496

497

498

499

500

501

502

503

504

505

Third, this review included two multifaceted interventions that addressed patients as well as HCPs and examined three patient-centered dimensions of medical care: the essential characteristics of the clinician (HCP), clinician-patient communication and patient information (Patterson et al. 2010; Westbury et al. 2010). These studies demonstrated that inappropriate users who were actively informed about appropriate BZD use were more likely to reduce or discontinue BZD use. In addition, HCPs who were informed and involved in active exchanges improved their prescribing behavior, which is consistent with other reviews (Grimshaw et al. 2001). The available evidence indicates that interventions that address both patients and HCPs are effective and have significant positive effects if patient information and HCP education are implemented simultaneously (Joosten et al. 2008; Loh et al. 2007). The joint distribution of information and educational resources to both groups stimulates information exchange, which can lead to the cessation of drug use and/or improvements in prescribing behaviors (Cook et al. 2007; Stewart et al. 2000). Therefore, it is important to use a combination of strategies, such as updating HCP skills and improving awareness among patients, to help reduce or discontinue BZD and z-drug use. Other studies have found that interdisciplinary collaborations in medication-care-related interventions also improve drug use outcomes (Zwarenstein et al. 2009). However, these results should be interpreted with caution, as only two studies were included in the present analysis.

When analyzing the identified articles, it became clear that general practitioners and nursing homes were attempting to reduce the inappropriate use of BZDs and z-drugs. This finding was particularly true for older people who were being treated on an outpatient basis or by nursing home personnel.

As reported in other published reviews, a number of interventions capable of reducing BZD and z-drug use already exist (Mugunthan et al. 2011; Voshaar et al. 2006). Interventions are more effective than routine care (Parr et al. 2006).

Consistent with previous reviews, interventions that target patients, which are represented under the dimension of patient information, have a positive effect on the reduction of BZD and z-drug use (Mugunthan et al. 2011). A brief intervention in the form of either a letter or a single consultation is an effective strategy to decrease or stop inappropriate medication use without causing adverse consequences (Mugunthan et al. 2011). Most strategies promote patient-centered care by providing information, boosting prescriber proficiency, and strengthening clinician-patient communication. Interventions that target patients and HCPs and use a multifaceted approach may be efficient, as studies of these interventions, in most cases, showed sustained reductions in BZD or z-drug use, consistent with other reviews (Gould et al. 2014). Our review emphasizes that there is a possibility of decreasing the inappropriate prescription and use of BZDs by providing patient-centered skills to providers. Finally, we found that effective interventions for changing clinical practice must target patients as well as HCPs and reflect the perspectives of patient-centered care (Dwamena et al. 2012; Legare et al. 2014).

Due to the heterogeneity of the included studies and their designs, this review did not attempt to compare the studies or make a final general statement. In addition, our findings and conclusions should be reconfirmed through further investigations.

\section{Strengths and limitations}

This is the first review of patient-centered care in the field of inappropriate BZD and z-drug usage. A systematic approach yielded a survey of patient-centered care interventions, providing a critical look at 
506 the multitude of methods that address different target groups along with their respective effectiveness.

507 The quality of the studies suffered considerably from a lack of specificity. Study protocols were missing

508 in all studies, and it was unclear whether all relevant information had been conveyed. Thus, it is necessary

509 to be cautious when interpreting these results. This review focused on the primary outcome of a reduction

510 in BZD and z-drug use and prescribing, and it did not consider secondary outcomes, such as the patients'

511 general health status (biological factors), social lives (social factors) or mental health status

512 (psychological outcomes). The HCPs were also not analyzed in terms of their duration in the profession

513 or their experience in treating older patients. An assessment of these factors is recommended in further

514 scientific investigations to obtain a complete understanding of the problems involved in the inappropriate

515 prescription and use of BZDs and z-drugs. Furthermore, one of the limitations is that although patient

516 education seems to be more effective than approaches regarding HCPs, caution must be practiced with

517 regard to generalization. A number of cognitively impaired older patients, especially in nursing homes

518 (e.g., dementia patients), are not able to benefit from educational information. Finally, many studies were

519 conducted using qualitative designs, and many were written in languages other than English; thus, these

520 studies were not included in the current review, though they may also have been relevant. Therefore,

521 future reviews should incorporate additional research designs.

522

523 Conclusion

524 The main finding of our systematic review is that patient information and educational strategies for HCPs

525 can effectively lead to the appropriate use and prescription of BZDs. All three examined areas of patient-

526 centered care (patient information, essential characteristics of the clinician and clinician-patient-

527 communication), alone or in combination, were generally effective at reducing and/or stopping the use of

528 BZDs and z-drugs completely. These results suggest that inappropriate BZD and z-drug users (older 529 adults) require and benefit from in-depth information about appropriate consumption. On the other hand, 530 HCPs require more interventions in which they may communicate their clinical experiences with other 531 groups of caregivers, discuss guidelines, and obtain additional knowledge to optimize their prescribing 532 practices. Although this review focused on a patient-centered approach, it also revealed the limitations of 533 studies that use this method. Before any final conclusions can be drawn, further investigations are needed 534 to reconfirm the findings discussed here.

535

536 Acknowledgements

537 We would like to thank Eva Christale for her collaboration in the screening and data extraction processes. 


\section{References}

539

540

541

542

543

544

545

546

547

548

549

550

551

552

553

554

555

556

557

558

559

560

561

562

563

564

565

566

567

568

569

570

571

572

573

574

575

576

577

578

579

580

581

582

583

584

American Geriatrics Society Beers Criteria Update Expert P. 2012. American Geriatrics Society updated Beers Criteria for potentially inappropriate medication use in older adults. Journal of the American Geriatrics Society 60:616-631. 10.1111/j.1532-5415.2012.03923.x

Anthierens S, Habraken H, Petrovic M, and Christiaens T. 2007a. The lesser evil? Initiating a benzodiazepine prescription in general practice. Scandinavian Journal of Primary Health Care 25:214-219. 10.1080/02813430701726335

Anthierens S, Habraken H, Petrovic M, Deveugele M, De Maeseneer J, and Christiaens T. 2007b. First benzodiazepine prescriptions: Qualitative study of patients' perspectives. Canadian Family Physician 53:1200-1201.

Ashton H. 2005. The diagnosis and management of benzodiazepine dependence. Current Opinion in Psychiatry 18:249-255.

Avorn J, Soumerai SB, Everitt DE, Ross-Degnan D, Beers MH, Sherman D, Salem-Schatz SR, and D. F. 1992. A randomized trial of a program to reduce the use of psychoactive drugs in nursing homes. The New England Journal of Medicine 327:168-173.

Barker MJ, Greenwood KM, Jackson M, and Crowe SF. 2004. Cognitive effects of long-term benzodiazepine use. CNS Drugs 18:37-48. 10.2165/00023210-200418010-00004

Bashir K, King M, and Ashworth M. 1994. Controlled evaluation of brief intervention by general practitioners to reduce chronic use of benzodiazepines. British Journal of General Practice 44:408-412.

Batty GM, Hooper R, Oborne CA, and Jackson SHD. 2001. Investigating intervention strategies to increase the appropriate use of benzodiazepines in elderly medical in-patients. British Journal of Clinical Governance 6:252-258. 10.1108/14664100110408608

Beers MH, and Ouslander JG. 1989. Risk factors in geriatric drug prescribing. A practical guide to avoiding problems. Drugs 37:105-112.

Berings D, Blondeel L, and Habraken H. 1994. The effect of industry-independent drug information on the prescribing of benzodiazepines in general practice. European journal of clinical pharmacology 46:501-505.

Bodenheimer T, Lorig K, Holman H, and Grumbach K. 2002. Patient self-management of chronic disease in primary care. JAMA 288:2469-2475.

Cochrane. data collection forms for intervention reviews. http://training.cochrane.org/resource/datacollection-forms-intervention-reviews.

Committee on Quality of Health Care in America loMI. 2001. Crossing the quality chasm: A new health system for the 21st century. Washington, C: The National Academies Press. National Academy of Sciences.

Cook JM, Marshall R, Masci C, and Coyne JC. 2007. Physicians' perspectives on prescribing benzodiazepines for older adults: a qualitative study. Journal of General Internal Medicine 22:303-307. 10.1007/s11606-006-0021-3

Cormack MA, Sweeney K, Hughes-Jones H, and Foot GA. 1994. Evaluation of an easy, cost-effective strategy for cutting benzodiazepine unse in general practice British Journal of General Practice 44:5-8.

Cunningham CM, Hanley GE, and Morgan S. 2010. Patterns in the use of benzodiazepines in British Columbia: examining the impact of increasing research and guideline cautions against long-term use. Health Policy 97:122-129.

Dixon-Woods M, Agarwal S, Jones D, Young B, and Sutton A. 2005. Synthesising qualitative and quantitative evidence: A review of possible methods. Journal of Health Services Research \& Policy 10:45-53. doi:10.1177/135581960501000110 
585

586

587

588

589

590

591

592

593

594

595

596

597

598

599

600

601

602

603

604

605

606

607

608

609

610

611

612

613

614

615

616

617

618

619

620

621

622

623

624

625

626

627

628

629

630

631

632

Dwamena F, Holmes-Rovner M, Gaulden CM, Jorgenson S, Sadigh G, Sikorskii A, Lewin S, Smith RC, Coffey J, and Olomu A. 2012. Interventions for providers to promote a patient-centred approach in clinical consultations. The Cochrane database of systematic reviews 12.

Epstein RM. 2000. The science of patient-centered care. Journal of Family Practice 49:805-810.

Fang SY, Chen CY, Chang IS, Wu EC, Chang CM, and Lin KM. 2009. Predictors of the incidence and discontinuation of long-term use of benzodiazepines: a population-based study. Drug and alcohol dependence 104:140-146. 10.1016/j.drugalcdep.2009.04.017

Farmer AP, Legare F, Turcot L, Grimshaw J, Harvey E, McGowan JL, and Wolf F. 2008. Printed educational materials: effects on professional practice and health care outcomes. The Cochrane database of systematic reviews:Cd004398. 10.1002/14651858.CD004398.pub2

Fassaert T, Dorn T, Spreeuwenberg PM, van Dongen MC, van Gool CJ, and Yzermans CJ. 2007. Prescription of benzodiazepines in general practice in the context of a man-made disaster: a longitudinal study. European journal of public health 17:612-617. 10.1093/eurpub/ckm020

Gorgels WJ, Oude Voshaar RC, Mol AJ, van de Lisdonk EH, van Balkom AJ, van den Hoogen HJ, Mulder J, Breteler MH, and Zitman FG. 2005. Discontinuation of long-term benzodiazepine use by sending a letter to users in family practice: a prospective controlled intervention study. Drug and alcohol dependence 78:49-56. 10.1016/j.drugalcdep.2004.09.001

Gould RL, Coulson MC, Patel N, Highton-Williamson E, and Howard RJ. 2014. Interventions for reducing benzodiazepine use in older people: meta-analysis of randomised controlled trials. The British journal of psychiatry : the journal of mental science 204:98-107. 10.1192/bjp.bp.113.126003

Grimshaw JM, Shirran L, Thomas R, Mowatt G, Fraser C, Bero L, Grilli R, Harvey E, Oxman A, and O'Brien MA. 2001. Changing provider behavior: an overview of systematic reviews of interventions. Medical Care 39:li2-45.

Harter M, Muller H, Dirmaier J, Donner-Banzhoff N, Bieber C, and Eich W. 2011. Patient participation and shared decision making in Germany - history, agents and current transfer to practice. Zeitschrift fur Evidenz, Fortbildung und Qualitat im Gesundheitswesen 105:263-270. 10.1016/j.zefq.2011.04.002

Heather N, Bowie A, Ashton H, McAvoy B, Spencer I, Brodie J, and Giddings D. 2004. Randomised controlled trial of two brief interventions against long-term benzodiazepine use: outcome of intervention. Addiction Research \& Theory 12:141-154. 10.1080/1606635310001634528

Higgins JP, Altman DG, Gotzsche PC, Juni P, Moher D, Oxman AD, Savovic J, Schulz KF, Weeks L, and Sterne JA. 2011. The Cochrane Collaboration's tool for assessing risk of bias in randomised trials. British Medical Journal 343:d5928. 10.1136/bmj.d5928

Huerta C, Abbing-Karahagopian V, Requena G, Oliva B, Alvarez Y, Gardarsdottir H, Miret M, Schneider C, Gil M, Souverein PC, De Bruin ML, Slattery J, De Groot MC, Hesse U, Rottenkolber M, Schmiedl S, Montero D, Bate A, Ruigomez A, Garcia-Rodriguez LA, Johansson S, de Vries F, Schlienger RG, Reynolds RF, Klungel OH, and de Abajo FJ. 2015. Exposure to benzodiazepines (anxiolytics, hypnotics and related drugs) in seven European electronic healthcare databases: a crossnational descriptive study from the PROTECT-EU Project. Pharmacoepidemiology and drug safety. 10.1002/pds.3825

Joosten EA, DeFuentes-Merillas L, De Weert G, Sensky T, Van Der Staak C, and de Jong CA. 2008. Systematic review of the effects of shared decision-making on patient satisfaction, treatment adherence and health status. Psychotherapy and psychosomatics 77:219-226.

Legare F, Stacey D, Turcotte S, Cossi MJ, Kryworuchko J, Graham ID, Lyddiatt A, Politi MC, Thomson R, Elwyn G, and Donner-Banzhoff N. 2014. Interventions for improving the adoption of shared decision making by healthcare professionals. Cochrane Database of Systematic Reviews 9.

Liberati A, Altman DG, Tetzlaff J, Mulrow C, Gøtzsche PC, loannidis JPA, Clarke M, Devereaux PJ, Kleijnen J, and Moher D. 2009. The PRISMA Statement for Reporting Systematic Reviews and Meta- 
633

634

635

636

637

638

639

640

641

642

643

644

645

646

647

648

649

650

651

652

653

654

655

656

657

658

659

660

661

662

663

664

665

666

667

668

669

670

671

672

673

674

675

676

677

678

679

680
Analyses of Studies That Evaluate Health Care Interventions: Explanation and Elaboration. PLOS Medicine 6:e1000100. 10.1371/journal.pmed.1000100

Loh A, Simon D, Kriston L, and Härter M. 2007. Patientenbeteiligung bei medizinischen Entscheidungen. Deutsches Ärzteblatt 104:A1483-A1488.

McAndrews MP, Weiss RT, Sandor P, Taylor A, Carlen PL, and Shapiro CM. 2003. Cognitive effects of long-term benzodiazepine use in older adults. Human psychopharmacology 18:51-57. 10.1002/hup.453

Mead N, and Bower P. 2000. Patient-centredness: a conceptual framework and review of the empirical literature. Social science \& medicine 51:1087-1110.

Mead N, and Bower P. 2002. Patient-centred consultations and outcomes in primary care: a review of the literature. Patient Education and Counseling 48:51-61.

Meador KG, Taylor JA, Thapa PB, Fought RL, and Ray WA. 1997. Predictors of antipsychotic withdrawal or dose reduction in randomized controlled trail of provider education. Journal of the American Geriatrics Society 45:207-210.

Mercer SW, Neumann M, Wirtz M, Fitzpatrick B, and Vojt G. 2008. General practitioner empathy, patient enablement, and patient-reported outcomes in primary care in an area of high socio-economic deprivation in Scotland--a pilot prospective study using structural equation modeling. Patient Education and Counseling 73:240-245.

Midlov P, Bondesson A, Eriksson T, Nerbrand C, and Hoglund P. 2006. Effects of educational outreach visits on prescribing of benzodiazepines and antipsychotic drugs to elderly patients in primary health care in southern Sweden. Family practice 23:60-64. 10.1093/fampra/cmi105

Moher D, Liberati A, Tetzlaff J, and Altman DG. 2009. Preferred reporting items for systematic reviews and meta-analyses: the PRISMA statement. British Medical Journal 339. 10.1136/bmj.b2535

Mugunthan K, McGuire T, and Glasziou P. 2011. Minimal interventions to decrease long-term use of benzodiazepines in primary care: a systematic review and meta-analysis. The British journal of general practice : the journal of the Royal College of General Practitioners 61:e573-578. 10.3399/bjgp11X593857

Opondo D, Eslami S, Visscher S, de Rooij SE, Verheij R, Korevaar JC, and Abu-Hanna A. 2012. Inappropriateness of medication prescriptions to elderly patients in the primary care setting: a systematic review. PloS one 7:e43617. 10.1371/journal.pone.0043617

Oshima Lee E, and Emanuel EJ. 2013. Shared Decision Making to Improve Care and Reduce Costs. New England Journal of Medicine 368:6-8. 10.1056/NEJMp1209500

Ottawa. 2014. Short-and Long-Term Use of Benzodiazepines in Patients with Generalized Anxiety Disorder: A Review of Guidelines: Canadian Agency for Drugs. Technology in Health.

Oude Voshaar RC, Gorgels WJ, Mol AJ, van Balkom AJ, Mulder J, van de Lisdonk EH, Breteler MH, and Zitman FG. 2006. Long-term outcome of two forms of randomised benzodiazepine discontinuation. The British journal of psychiatry : the journal of mental science 188:188-189. 10.1192/bjp.bp.105.012039

Parr JM, Kavanagh DJ, Young RM, and McCafferty K. 2006. Views of general practitioners and benzodiazepine users on benzodiazepines: a qualitative analysis. Social science $\&$ medicine 62:1237-1249.

Paterniti S, Dufouil C, and Alperovitch A. 2002. Long-term benzodiazepine use and cognitive decline in the elderly: the Epidemiology of Vascular Aging Study. Journal of Clinical Psychopharmacol 22:285-293.

Patterson SM, Hughes CM, Crealey G, Cardwell C, and Lapane KL. 2010. An evaluation of an adapted U.S. model of pharmaceutical care to improve psychoactive prescribing for nursing home residents in northern ireland (fleetwood northern ireland study). Journal of the American Geriatrics Society 58:44-53. 10.1111/j.1532-5415.2009.02617.x 
681

682

683

684

685

686

687

688

689

690

691

692

693

694

695

696

697

698

699

700

701

702

703

704

705

706

707

708

709

710

711

712

713

714

715

716

717

718

719

720

721

722

723

724

725

726

727

Phelan M, Stradins L, and Morrison S. 2001. Towards a global definition of patient centred care. Psychiatry 155:974-976.

Pimott NJG, Hux JE, Wilson LM, Kahan M, Li C, and Rosser WW. 2003. Educating physicians to reduce benzodiazepine use by elderly patients: a randomized controlled trial. Canadian Medical Association Journal 168:835-839.

Pit SW, Byles JE, Henry DA, Holt L, Hansen V, and Bowman A. 2007. A quality use of medicines program for general practitioners and older people: a cluster randomised controlled trial. The Medical journal of Australia 187:23-30.

Rao JK, Anderson LA, Inui TS, and Frankel RM. 2007. Communication Interventions Make A Difference in Conversations Between Physicians and Patients: A Systematic Review of the Evidence. Medical Care 45:340-349. 10.1097/01.mlr.0000254516.04961.d5

Rathert C, Wyrwich MD, and Boren SA. 2012. Patient-centered care and outcomes: a systematic review of the literature. Medical Care Research and Review 70:(4):351-379 $10.1177 / 1077558712465774$

Rickels K, Schweizer E, Case WG, and Greenblatt DJ. 1990. Long-term therapeutic use of benzodiazepines. I. Effects of abrupt discontinuation. Archives of general psychiatry 47:899-907.

Roberts MS, Stokes JA, King MA, Lynne TA, Purdie DM, Glasziou PP, Wilson AJ, McCarthy ST, Brooks GE, de Looze FJ, and Del Mar CB. 2001. Outcomes of a randomized controlled tiral of clinical pharmacy intervention in 52 nursing homes British Journal of Clinical Pharmacology 51:257-265.

Rogers A, Pilgrim D, Brennan S, Sulaiman I, Watson G, and Chew-Graham C. 2007. Prescribing benzodiazepines in general practice: a new view of an old problem. Health (London, England : 1997) 11:181-198. 10.1177/1363459307074693

Scholl I, Zill JM, Harter M, and Dirmaier J. 2014. An integrative model of patient-centeredness - a systematic review and concept analysis. PloS one. https://doi.org/10.1371/journal.pone.0107828

Smith AJ, and Tett SE. 2010. An intervention to improve benzodiazepine use--a new approach. Family practice 27:320-327. 10.1093/fampra/cmq007

Smith DH, Christensen DB, Stergachis A, and Holmes G. 1998. A randomized controlled trial of a drug use review intervention for sedative hypnotic medications. Medial Care 36:1013-1021.

Stewart M, Brown JB, Donner A, McWhinney IR, Oates J, Weston WW, and Jordan J. 2000. The impact of patient-centered care on outcomes. The Journal of family practice 49:796-804.

Stewart R, Niessen WJ, Broer J, Snijders TA, Haaijer-Ruskamp FM, and Meyboom-De Jong B. 2007. General Practitioners reduced benzodiazepine prescriptions in an intervention study: a multilevel application. Journal of clinical epidemiology 60:1076-1084. 10.1016/j.jclinepi.2006.11.024

Takkouche B, Montes-Martinez A, Gill SS, and Etminan M. 2007. Psychotropic medications and the risk of fracture: a meta-analysis. Drug Safety 30:171-184.

Tannenbaum C, Martin P, Tamblyn R, Benedetti A, and Ahmed S. 2014. Reduction of inappropriate benzodiazepine prescriptions among older adults through direct patient education: the EMPOWER cluster randomized trial. JAMA internal medicine 174:890-898. 10.1001/jamainternmed.2014.949

Ten Wolde GB, Dijkstra A, van Empelen P, van den Hout W, Neven AK, and Zitman F. 2008. Long-term effectiveness of computer-generated tailored patient education on benzodiazepines: a randomized controlled trial. Addiction 103:662-670. 10.1111/j.1360-0443.2008.02141.x

Vicens C, Bejarano F, Sempere E, Mateu C, Fiol F, Socias I, Aragones E, Palop V, Beltran JL, Pinol JL, Lera G, Folch S, Mengual M, Basora J, Esteva M, Llobera J, Roca M, Gili M, and Leiva A. 2014. Comparative efficacy of two interventions to discontinue long-term benzodiazepine use: cluster 
randomised controlled trial in primary care. The British journal of psychiatry : the journal of mental science 204:471-479. 10.1192/bjp.bp.113.134650

Vicens C, Fiol F, Llobera J, Campoamor F, Mateu C, Alegret S, and Socías I. 2006. Withdrawal from longterm benzodiazepine use: randomised trial in family practice. British Journal of General Practice 56:958-963.

Voshaar RCO, Couvée JE, Van Balkom AJLM, Mulder PGH, and Zitman FG. 2006. Strategies for discontinuing long-term benzodiazepine use. Meta-analysis. The British Journal of Psychiatry 189:213-220. 10.1192/bjp.189.3.213

Voyer P, Preville M, Roussel ME, Berbiche D, and Beland SG. 2009. Factors associated with benzodiazepine dependence among community-dwelling seniors. Journal of Community Health Nursing 26:101-113.

Westbury J, Jackson S, Gee P, and Peterson G. 2010. An effective approach to decrease antipsychotic and benzodiazepine use in nursing homes: the RedUSe project. International psychogeriatrics / IPA 22:26-36. 10.1017/S1041610209991128

Zill JM, Scholl I, Härter M, and Dirmaier J. 2015. Which Dimensions of Patient-Centeredness Matter? Results of a Web-Based Expert Delphi Survey. PloS one 10:e0141978. 10.1371/journal.pone.0141978

Zint K, Haefeli WE, Glynn RJ, Mogun H, Avorn J, and Sturmer T. 2010. Impact of drug interactions, dosage, and duration of therapy on the risk of hip fracture associated with benzodiazepine use in older adults. Pharmacoepidemiology and drug safety 19:1248-1255.

Zolnierek KB, and Dimatteo MR. 2009. Physician communication and patient adherence to treatment: a meta-analysis. Medical Care 47:826-834.

Zwarenstein M, Goldman J, and Reeves S. 2009. Interprofessional collaboration: effects of practicebased interventions on professional practice and healthcare outcomes. Cochrane Database of Systematic Reviews. 10.1002/14651858.CD000072.pub2 
Figure 1 (on next page)

Flow diagram of studies reviewed 


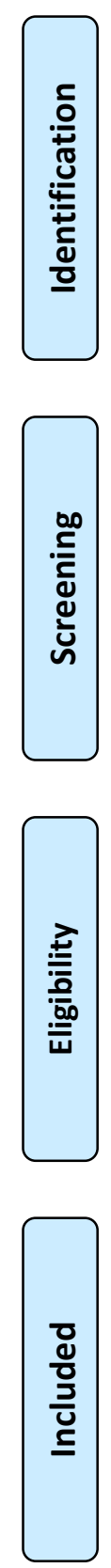

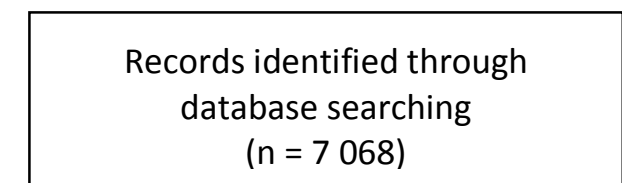

$(n=7068)$
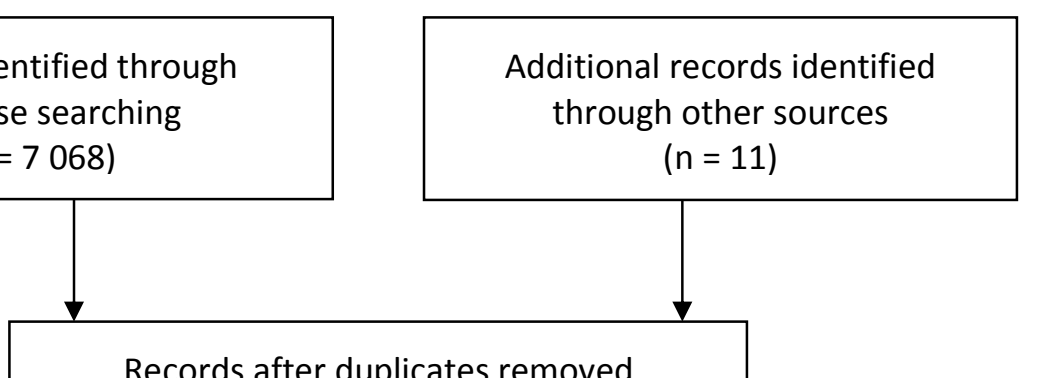

Records after duplicates removed

$(n=4628)$

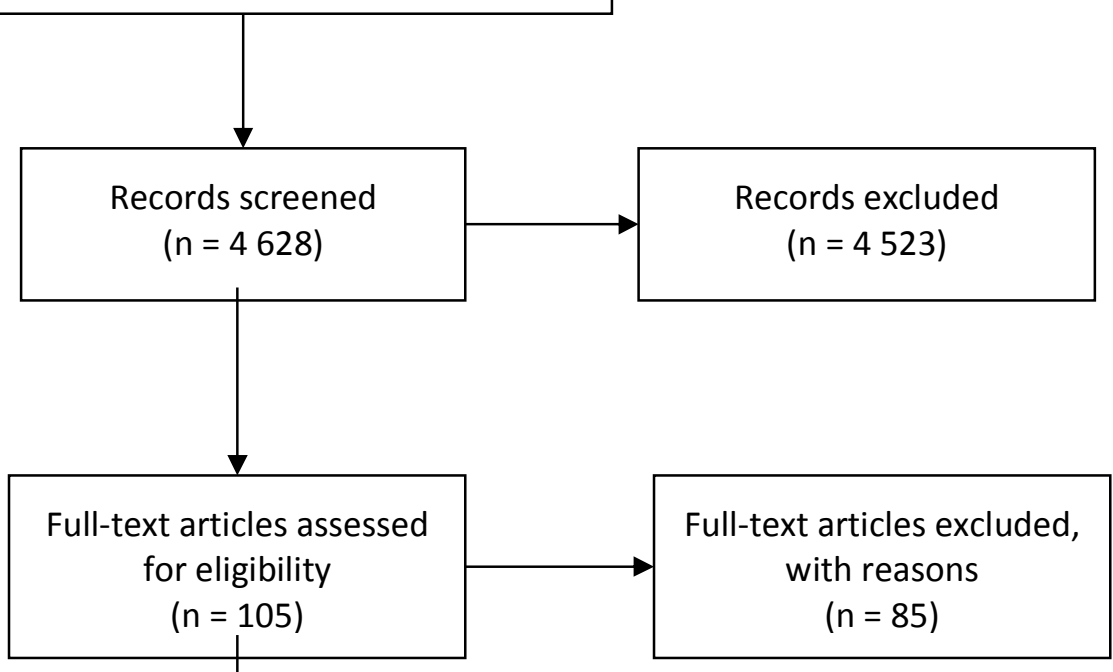

Studies included in

synthesis

$(n=20)$ 
Table $\mathbf{1}$ (on next page)

Description of included studies: patients 
1 Table 1: description of included studies- interventions regarding patients

\begin{tabular}{|c|c|c|c|c|c|c|c|c|c|c|}
\hline $\begin{array}{l}\text { referenc } \\
\text { e }\end{array}$ & title & $\begin{array}{l}\text { locat } \\
\text { ion }\end{array}$ & $\begin{array}{l}\text { desig } \\
\text { n }\end{array}$ & setting & duration & $\begin{array}{l}\text { sample } \\
\text { total } n\end{array}$ & $\begin{array}{l}\text { sample description: } \\
\text { definition, mean age, sex } \\
\text { distribution, groups }\end{array}$ & intervention & $\begin{array}{l}\text { dimension of } \\
\text { patient- } \\
\text { centered- } \\
\text { care model }\end{array}$ & findings \\
\hline $\begin{array}{l}\text { Bashir et } \\
\text { al., } 1994\end{array}$ & $\begin{array}{l}\text { Controlled } \\
\text { evaluation of brief } \\
\text { intervention by } \\
\text { general } \\
\text { practitioners to } \\
\text { reduce chronic use } \\
\text { of } \\
\text { benzodiazepines }\end{array}$ & UK & CT & $\begin{array}{l}\text { general } \\
\text { practices }\end{array}$ & 6 months & 109 & $\begin{array}{l}\text { chronic BZDs users, M=62 } \\
\text { years, } 61 \% \text { women } \\
\text { intervention group ( } 51) \\
\text { control group ( } 58)\end{array}$ & $\begin{array}{l}\text { a self-help booklet included } \\
\text { general information about } \\
\text { benzodiazepine \& techniques of } \\
\text { coping with fears \& anxiety } \\
\text { supported with physician's } \\
\text { advice }\end{array}$ & $\begin{array}{l}\text { patient } \\
\text { information }\end{array}$ & $\begin{array}{l}\text { Eighteen per cent of patients in the } \\
\text { intervention group }(9 / 50) \text { had a reduction in } \\
\text { benzodiazepine prescribing recorded in the } \\
\text { notes compared with } 5 \% \text { of the } 55 \text { patients in } \\
\text { the control group }(\mathrm{P}<0.05) \text {. }\end{array}$ \\
\hline $\begin{array}{l}\text { Cormack } \\
\text { et al., } \\
1994\end{array}$ & 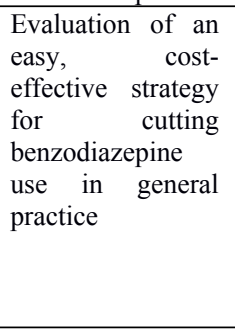 & UK & CT & $\begin{array}{l}\text { general } \\
\text { practices }\end{array}$ & 6 months & 209 & $\begin{array}{l}\text { long-term regular users of } \\
\text { BZDs, M=69 years, 4:1 } \\
\text { women to men } \\
\text { letter group (65) } \\
\text { letter plus advice group (75) } \\
\text { control group (69) }\end{array}$ & $\begin{array}{l}\text { discontinuation letter asked the } \\
\text { patient to reduce or stop the } \\
\text { medication gradually and } \\
\text { provide information about } \\
\text { reducing medication \& practical } \\
\text { suggestions for } \\
\text { nonpharmacological coping } \\
\text { strategies } \\
\begin{array}{l}\text { plus 4- monthly information } \\
\text { sheets }\end{array}\end{array}$ & $\begin{array}{l}\text { patient } \\
\text { information }\end{array}$ & $\begin{array}{l}\text { After six months, both intervention groups } \\
\text { had reduced their consumption to } \\
\text { approximately two thirds of the original } \\
\text { intake of benzodiazepines and there was a } \\
\text { statistically significant difference between the } \\
\text { groups. } 18 \% \text { of those receiving the } \\
\text { interventions received no prescriptions at all } \\
\text { during the six month monitoring period. }\end{array}$ \\
\hline $\begin{array}{l}\text { Gorgels } \\
\text { et al., } \\
2005\end{array}$ & $\begin{array}{l}\text { Discontinuation of } \\
\text { long-term } \\
\text { benzodiazepine } \\
\text { use by sending a } \\
\text { letter to users in } \\
\text { family practice: a } \\
\text { prospective } \\
\text { controlled } \\
\text { intervention study }\end{array}$ & $\begin{array}{l}\text { Neth } \\
\text { er- } \\
\text { lands }\end{array}$ & $\mathrm{CT}$ & $\begin{array}{l}\text { family } \\
\text { practices }\end{array}$ & $\begin{array}{l}\text { 6- } 21 \\
\text { months }\end{array}$ & 4416 & $\begin{array}{l}\text { long-term BZDs users, M=68 } \\
\text { years, } 65 \% \text { - } 69 \% \text { women } \\
\text { experimental group }(2595) \\
\text { control group }(1821)\end{array}$ & $\begin{array}{l}\text { patient information as a } \\
\text { discontinuation letter advised to } \\
\text { gradually stop benzodiazepine } \\
\text { use supported with patient- } \\
\text { physician-communication, } \\
\text { which evaluated actual } \\
\text { benzodiazepine use }\end{array}$ & $\begin{array}{l}\text { patient } \\
\text { information }\end{array}$ & $\begin{array}{l}\text { At } 6 \text { months a large reduction in } \\
\text { benzodiazepine prescription was present of } \\
24 \% \text { in the experimental group, versus } 5 \% \text { in } \\
\text { the control group. At } 21 \text { months again a } \\
\text { steady reduction in benzodiazepine } \\
\text { prescription of } 26 \% \text { was observed in the } \\
\text { experimental group, versus } 9 \% \text { in the control } \\
\text { group, indicating that the short-term gain of } \\
\text { the intervention was preserved. }\end{array}$ \\
\hline
\end{tabular}




\begin{tabular}{|c|c|c|c|c|c|c|c|c|c|c|}
\hline $\begin{array}{l}\text { referenc } \\
\text { e }\end{array}$ & title & $\begin{array}{l}\text { locat } \\
\text { ion }\end{array}$ & $\begin{array}{l}\text { desig } \\
\mathrm{n}\end{array}$ & setting & duration & $\begin{array}{l}\text { sample } \\
\text { total } n\end{array}$ & $\begin{array}{l}\text { sample description: } \\
\text { definition, mean age, } \\
\text { sex distribution, } \\
\text { groups }\end{array}$ & intervention & $\begin{array}{l}\text { dimension of } \\
\text { patient- } \\
\text { centered- } \\
\text { care model }\end{array}$ & findings \\
\hline $\begin{array}{l}\text { Tannen- } \\
\text { baum et } \\
\text { al., } 2014\end{array}$ & $\begin{array}{l}\text { Reduction of } \\
\text { inappropriate } \\
\text { benzodiazepine } \\
\text { prescriptions } \\
\text { among older } \\
\text { adults through } \\
\text { direct patient } \\
\text { education: } \\
\text { The EMPOWER } \\
\text { Cluster }\end{array}$ & $\begin{array}{l}\text { Cana } \\
\text { da }\end{array}$ & RCT & $\begin{array}{l}\text { community } \\
\text { pharmacies }\end{array}$ & 6 months & 303 & $\begin{array}{l}\text { long-term BZDs users, } \\
M=75 \text { years, } 69 \% \\
\text { women } \\
\text { intervention group } \\
\text { (138) } \\
\text { control group (155) }\end{array}$ & $\begin{array}{l}\text { patient information via a } \\
\text { personalized booklet comprising a } \\
\text { self-assessment component } \\
\text { including risks \& advice about drug } \\
\text { interactions \& mentioning evidence, } \\
\text { tapering recommendations \& } \\
\text { therapeutic substitutes as well as } \\
\text { knowledge statements \& peer } \\
\text { champion theories to create } \\
\text { cognitive dissonance about the } \\
\text { safety of the benzodiazepine intake } \\
\text { \& augment self-efficacy }\end{array}$ & $\begin{array}{l}\text { patient } \\
\text { information }\end{array}$ & $\begin{array}{l}\text { At } 6 \text { months, } 27 \% \text { of the intervention group } \\
\text { had discontinued benzodiazepine use } \\
\text { compared with } 5 \% \text { of the control group (risk } \\
\text { difference, } 23 \% \quad[95 \% \text { CI, } 14 \%-32 \%] \text {; } \\
\text { intracluster correlation, } 0.008 ; \text { number } \\
\text { needed to treat, 4). Dose reduction occurred } \\
\text { in an additional } 11 \%(95 \% \mathrm{CI}, 6 \%-16 \%) \text {. }\end{array}$ \\
\hline $\begin{array}{l}\text { Ten } \\
\text { Wolde et } \\
\text { al., } 2008\end{array}$ & $\begin{array}{l}\text { Long-term } \\
\text { effectiveness of } \\
\text { computer- } \\
\text { generated } \\
\text { tailored patient } \\
\text { education on } \\
\text { benzodiazepines: } \\
\text { a randomized } \\
\text { controlled trial }\end{array}$ & $\begin{array}{l}\text { Neth } \\
\text { erlan } \\
\text { ds }\end{array}$ & RCT & $\begin{array}{l}\text { general } \\
\text { practices }\end{array}$ & $\begin{array}{l}12 \\
\text { months }\end{array}$ & 695 & $\begin{array}{l}\text { chronic BZDs users, } \\
\mathrm{M}=62.3 \text { years, } 68.1 \\
\text { women } \\
\text { single tailored letter } \\
(163) \\
\text { multiple tailored letter } \\
(186) \quad \\
\text { general practitioner } \\
\text { letter (159) }\end{array}$ & $\begin{array}{l}\text { patient information either via two } \\
\text { individual tailored letters aiming to } \\
\text { reduce the positive outcome } \\
\text { expectation of benzodiazepines by } \\
\text { bearing in mind benefits of its } \\
\text { withdrawal \& in this case increasing } \\
\text { self-efficacy expectations or a short } \\
\text { general practitioner letter that } \\
\text { modelled usual care }\end{array}$ & $\begin{array}{l}\text { patient } \\
\text { information }\end{array}$ & $\begin{array}{l}\text { Among participants with the intention to } \\
\text { discontinue usage at baseline, both tailored } \\
\text { interventions led to high percentages of those } \\
\text { who actually discontinued usage (single } \\
\text { tailored intervention } 51.7 \% \text {; multiple tailored } \\
\text { intervention } 35.6 \% \text {; general practitioner letter } \\
14.5 \% \text { ). }\end{array}$ \\
\hline $\begin{array}{l}\text { Stewart et } \\
\text { al., } \\
2007\end{array}$ & $\begin{array}{l}\text { General } \\
\text { practitioners } \\
\text { reduced } \\
\text { benzodiazepine } \\
\text { prescriptions in an } \\
\text { intervention study: } \\
\text { a multilevel } \\
\text { application }\end{array}$ & $\begin{array}{l}\text { Neth } \\
\text { erlan } \\
\text { ds }\end{array}$ & $\mathrm{CT}$ & $\begin{array}{l}\text { general } \\
\text { practices }\end{array}$ & $\begin{array}{l}12 \\
\text { months }\end{array}$ & 8179 & $\begin{array}{l}\text { chronic BZDs users, } \\
\mathrm{M}=64.63 \text { years, } 73.2 \% \\
\text { women } \\
\text { intervention group (19 } \\
\text { general practices) } \\
\text { control group (128 } \\
\text { general practices) }\end{array}$ & $\begin{array}{l}\text { patient information as a } \\
\text { discontinuation letter outlined } \\
\text { information about the risks of } \\
\text { continuous use of benzodiazepines } \\
\text { \& recommended their withdrawal by } \\
\text { inviting patients to an appointment } \\
\text { to discuss this procedure, followed } \\
\text { by an information leaflet about } \\
\text { BZDs. }\end{array}$ & $\begin{array}{l}\text { patient } \\
\text { information } \\
\text { and clinician- } \\
\text { patient } \\
\text { communicatio } \\
\mathrm{n}\end{array}$ & $\begin{array}{l}\text { Sending a letter to chronic long-term users of } \\
\text { benzodiazepines advising decreasing or } \\
\text { stopping benzodiazepine use in general } \\
\text { practice resulted in a } 16 \% \text { reduction after } 6 \\
\text { months and a } 14 \% \text { reduction after } 1 \text { year. }\end{array}$ \\
\hline
\end{tabular}




\begin{tabular}{|c|c|c|c|c|c|c|c|c|c|c|}
\hline $\begin{array}{l}\text { Heather } \\
\text { et al., } \\
2004\end{array}$ & $\begin{array}{l}\text { Randomized } \\
\text { controlled trial of } \\
\text { two bo brief } \\
\text { interventions } \\
\text { against long-term } \\
\text { benzodiazepine } \\
\text { use: outcome of } \\
\text { intervention }\end{array}$ & UK & RCT & $\begin{array}{l}\text { general } \\
\text { practices }\end{array}$ & 6 months & 284 & $\begin{array}{l}\text { long-term BZDs users, } \\
M=69.1 \text { years, } 48 \% \\
\text { females } \\
\text { letter group (93) } \\
\text { consultation group (98) } \\
\text { control group (93) }\end{array}$ & $\begin{array}{l}\text { patient information via self-help } \\
\text { booklet included information about } \\
\text { tranquilizers, sleeping tablets \& their } \\
\text { withdrawal accompanied by a leaflet } \\
\text { about sleeping problems and a } \\
\text { discontinuation letter which } \\
\text { informed about risks \& advised to } \\
\text { stop the intake, supported with } \\
\text { patient-physician-communication } \\
\text { including general information about } \\
\text { benzodiazepines as well as } \\
\text { advantages of \& guidelines for } \\
\text { withdrawal }\end{array}$ & $\begin{array}{l}\text { patient } \\
\text { information } \\
\text { and clinician- } \\
\text { patient } \\
\text { communicatio } \\
\mathrm{n}\end{array}$ & $\begin{array}{l}\text { Results showed significantly larger } \\
\text { reductions in BZDS consumption in the letter } \\
(24 \% \text { overall) and consultation } \\
(22 \%) \text { groups than the control group ( } 16 \%) \\
\text { but no significant difference between the two } \\
\text { interventions. }\end{array}$ \\
\hline $\begin{array}{l}\text { Vicens et } \\
\text { al., } \\
2006\end{array}$ & $\begin{array}{l}\text { Withdrawal from } \\
\text { long-term } \\
\text { benzodiazepine } \\
\text { use: randomized } \\
\text { trial in family } \\
\text { practice }\end{array}$ & $\begin{array}{l}\text { Spai } \\
\mathrm{n}\end{array}$ & RCT & $\begin{array}{l}\text { public } \\
\text { primary } \\
\text { care centers }\end{array}$ & $\begin{array}{l}12 \\
\text { months }\end{array}$ & 139 & $\begin{array}{l}\text { long-term BZDs users, } \\
\mathrm{M}=59 \text { years, } 82 \% \\
\text { women } \\
\text { intervention group (73) } \\
\text { control group (66) }\end{array}$ & $\begin{array}{l}\text { patient information via physicians' } \\
\text { interview given on the first \& follow } \\
\text { up visits: first visit concentrated } \\
\text { mostly on general information about } \\
\text { benzodiazepines \& their } \\
\text { risks/effects, while the follow up } \\
\text { visits focused on positive } \\
\text { reinforcement of achievements }\end{array}$ & $\begin{array}{l}\text { patient } \\
\text { informtion } \\
\text { and clinician- } \\
\text { patient } \\
\text { communi- } \\
\text { cation }\end{array}$ & $\begin{array}{l}\text { After } 12 \text { months, } 33(45.2 \%) \text { patients in the } \\
\text { intervention group and six }(9.1 \%) \text { in the } \\
\text { control group had discontinued } \\
\text { benzodiazepine use; relative risk }=4.97(95 \% \\
\text { confidence interval }[\mathrm{CI}]=2.2 \text { to } 11.1) \text {, } \\
\text { absolute risk reduction }=0.36(95 \% \mathrm{CI}=0.22 \\
\text { to } 0.50) \text {. Sixteen }(21.9 \%) \text { subjects from the } \\
\text { intervention group and } 11(16.7 \%) \text { controls } \\
\text { reduced their initial dose by more than } 50 \% \text {. }\end{array}$ \\
\hline $\begin{array}{l}\text { Vicens et } \\
\text { al., } \\
2014\end{array}$ & $\begin{array}{l}\text { Comparative } \\
\text { efficacy of two } \\
\text { interventions to } \\
\text { discontinue long- } \\
\text { term } \\
\text { benzodiazepine } \\
\text { use: cluster } \\
\text { randomized } \\
\text { controlled trial in } \\
\text { primary care }\end{array}$ & $\begin{array}{l}\text { Spai } \\
\mathrm{n}\end{array}$ & RCT & $\begin{array}{l}\text { general } \\
\text { practices }\end{array}$ & $\begin{array}{l}12 \\
\text { months }\end{array}$ & 532 & $\begin{array}{l}\text { long-term BZDs users, } \\
\mathrm{M}=64 \text { years, } 72 \% \\
\text { women } \\
\text { structured intervention } \\
\text { (SIF) (191) } \\
\text { structured intervention } \\
\text { with } \quad \text { written } \\
\text { instructions (SIW) } \\
(168) \\
\text { control group (173) }\end{array}$ & $\begin{array}{l}\text { educational intervention for patients } \\
\text { with fortnightly follow-up visits to } \\
\text { support gradual tapering (SIF) and } \\
\text { written information material for } \\
\text { patients rather than follow-up visits } \\
\text { (SIW); } \\
\text { patient information via educational } \\
\text { interview included an information } \\
\text { on benzodiazepine dependence, } \\
\text { abstinence \& withdrawal symptoms, } \\
\text { risks of long-term use \& reassurance } \\
\text { about reducing medication as well as } \\
\text { a self-help leaflet to improve sleep } \\
\text { quality }\end{array}$ & $\begin{array}{l}\text { patient } \\
\text { information, } \\
\text { clinician- } \\
\text { patient } \\
\text { communi- } \\
\text { cation and } \\
\text { essential } \\
\text { characteristics } \\
\text { of the } \\
\text { clinician }\end{array}$ & $\begin{array}{l}\text { At } 12 \text { months, } 76 \text { of } 168(45 \%) \text { patients in the } \\
\text { SIW group and } 86 \text { of } 191(45 \%) \text { in the SIF } \\
\text { group had discontinued benzodiazepine use } \\
\text { compared with } 26 \text { of } 173(15 \%) \text { in the control } \\
\text { group. } \\
\text { Both interventions led to significant } \\
\text { reductions in long-term benzodiazepine use } \\
\text { in patients without severe comorbidity. }\end{array}$ \\
\hline
\end{tabular}


Table 2 (on next page)

Description of included studies: health care professionals 
1 Table 1: description of included studies- interventions regarding health care professionals

\begin{tabular}{|c|c|c|c|c|c|c|c|c|c|c|}
\hline $\begin{array}{l}\text { referenc } \\
\text { e }\end{array}$ & title & $\begin{array}{l}\text { locat } \\
\text { ion }\end{array}$ & $\begin{array}{l}\text { desig } \\
\text { n }\end{array}$ & setting & duration & $\begin{array}{l}\text { sample } \\
\text { total n }\end{array}$ & $\begin{array}{l}\text { sample description: } \\
\text { definition, mean age, } \\
\text { sex distribution, groups }\end{array}$ & Intervention & $\begin{array}{l}\text { dimension of } \\
\text { patient- } \\
\text { centered-care } \\
\text { model }\end{array}$ & findings \\
\hline $\begin{array}{l}\text { Avorn et } \\
\text { al., } \\
1992\end{array}$ & $\begin{array}{l}\text { A randomized trial } \\
\text { of a program to } \\
\text { reduce the use of } \\
\text { psychoactive } \\
\text { drugs in nursing } \\
\text { home }\end{array}$ & USA & $\mathrm{RCT}$ & $\begin{array}{l}\text { nursing } \\
\text { home }\end{array}$ & 5 months & 823 & $\begin{array}{l}\text { long-time users of } \\
\text { psychoactive drugs and } \\
\text { BZDs, not reported } \\
\text { intervention group of } 6 \\
\text { nursing homes (431) } \\
\text { control group of } 6 \\
\text { nursing homes (392) }\end{array}$ & $\begin{array}{l}\text { educational program to improve } \\
\text { medical competence based on the } \\
\text { principles of "academic detailing", } \\
\text { which focuses on direct patient care, } \\
\text { alternatives to psychoactive drugs \& } \\
\text { recognition of adverse drug } \\
\text { reactions } \\
\text { face-to-face educational sessions by } \\
\text { clinical pharmacists for prescribers } \\
\text { and written information material for } \\
\text { prescribers }\end{array}$ & $\begin{array}{l}\text { essential } \\
\text { characteristics } \\
\text { of the clinician } \\
\text { and clinician- } \\
\text { patient } \\
\text { communication }\end{array}$ & $\begin{array}{l}\text { Significant reduce psychoactive drug use in } \\
\text { experimental group than in control }(27 \% \\
\text { vs. } 8 \%, p=0.02) \text {. The comparable figures } \\
\text { for the discontinuation of long-acting } \\
\text { benzodiazepines were } 20 \% \text { vs.. } 9 \% \text { (no } \\
\text { significant). }\end{array}$ \\
\hline $\begin{array}{l}\text { Batty et } \\
\text { al., } 2001\end{array}$ & $\begin{array}{l}\text { Investigating } \\
\text { intervention } \\
\text { strategies to } \\
\text { increase the } \\
\text { appropriate use of } \\
\text { benzodiazepines } \\
\text { in elderly medical } \\
\text { in-patients }\end{array}$ & UK & $\mathrm{RCT}$ & hospitals & $\begin{array}{l}6-12 \\
\text { months }\end{array}$ & 1414 & $\begin{array}{l}\text { inappropriate BZDs } \\
\text { users, } M=75 \text { years, not } \\
\text { reported } \\
\text { verbal intervention (not } \\
\text { reported) } \\
\text { bulletin intervention (not } \\
\text { reported) } \\
\text { control group (not } \\
\text { reported) }\end{array}$ & $\begin{array}{l}\text { verbal intervention delivered in an } \\
\text { interactive lecture format by a } \\
\text { physician and a pharmacist to an } \\
\text { audience arranged by the hospital } \\
\text { contact. Bulletin intervention } \\
\text { involved dissemination of printed } \\
\text { material to physicians, pharmacist } \\
\text { and nurses involved in the care at the } \\
\text { hospital. }\end{array}$ & $\begin{array}{l}\text { essential } \\
\text { characteristics } \\
\text { of the clinician } \\
\text { and clinician- } \\
\text { patient } \\
\text { communication }\end{array}$ & $\begin{array}{l}\text { Appropriate prescribing following verbal } \\
\text { intervention increased substantially from } \\
29 \% \text { to } 44 \% \text { but this did not achieve } \\
\text { statistical significance. There was a } \\
\text { reduction in appropriate prescribing } \\
\text { following bulletin intervention ( } 42 \% \text { to } \\
33 \% \text { ) and no change following control } \\
\text { intervention ( } 42 \% \text { to } 42 \%) \text {. }\end{array}$ \\
\hline $\begin{array}{l}\text { Berings } \\
\text { et } \\
\text { al.,1994 }\end{array}$ & $\begin{array}{l}\text { The effect of } \\
\text { industry- } \\
\text { independent drug } \\
\text { information on the } \\
\text { prescribing of } \\
\text { benzodiazepines } \\
\text { in general practice }\end{array}$ & $\begin{array}{l}\text { Belgi } \\
\text { um }\end{array}$ & RCT & $\begin{array}{l}\text { general } \\
\text { practices }\end{array}$ & 4 weeks & 128 & $\begin{array}{l}\text { general practitioners, not } \\
\text { reported } \\
\text { oral and written } \\
\text { information (44) } \\
\text { written information (43) } \\
\text { no information (41) }\end{array}$ & $\begin{array}{l}\text { educational mail arguing for the } \\
\text { rational \& short-term prescribing of } \\
\text { benzodiazepines, contained specific } \\
\text { information regarding the limited } \\
\text { effectiveness of long-term } \\
\text { benzodiazepine use, risks \& } \\
\text { different forms of habituation \& } \\
\text { dependence supported by an } \\
\text { independent medical representative } \\
\text { whose oral message was congruent } \\
\text { with the written materials \& who } \\
\text { answered any questions }\end{array}$ & $\begin{array}{l}\text { essential } \\
\text { characteristics } \\
\text { of the clinician }\end{array}$ & $\begin{array}{l}\text { The absolute reduction in the number of } \\
\text { prescribed packages was highest in } \\
\text { condition one (oral and written } \\
\text { information) with a mean decrease of } 24 \% \\
\text { compared to the baseline. A reduction of } \\
14 \% \text { was found in physicians of condition } \\
\text { two (written information) and of } 3 \% \text { in the } \\
\text { control group. }\end{array}$ \\
\hline
\end{tabular}




\begin{tabular}{|c|c|c|c|c|c|c|c|c|c|c|}
\hline $\begin{array}{l}\text { Midlöv et } \\
\text { al., } \\
2006\end{array}$ & $\begin{array}{l}\text { Effects of } \\
\text { educational } \\
\text { outreach visits on } \\
\text { prescribing } \\
\text { of } \\
\text { benzodiazepines } \\
\text { and antipsychotic } \\
\text { drugs to elderly } \\
\text { patients in primary } \\
\text { health care in } \\
\text { southern Sweden }\end{array}$ & $\begin{array}{l}\text { Swe } \\
\text { den }\end{array}$ & RCT & $\begin{array}{l}\text { general } \\
\text { practices }\end{array}$ & $\begin{array}{l}12 \\
\text { months }\end{array}$ & 54 & $\begin{array}{l}\text { physicians in general } \\
\text { practices, not reported } \\
\text { (not reported) } \\
\text { intervention group (23) } \\
\text { control group (31) }\end{array}$ & $\begin{array}{l}\text { physician's \& pharmacist's visits in } \\
2-8 \text { week intervals: the first visit } \\
\text { dealt with different causes of } \\
\text { confusion in the elderly like } \\
\text { medications, infections \& other } \\
\text { illnesses while discussing associated } \\
\text { literature, whereas the second visit } \\
\text { focused on the effects \& risks of } \\
\text { benzodiazepine use with medium or } \\
\text { long acting duration of medication } \\
\text { action }\end{array}$ & $\begin{array}{l}\text { essential } \\
\text { characteristics } \\
\text { of the clinician }\end{array}$ & $\begin{array}{l}\text { One year after the educational outreach } \\
\text { visits there were significant decreases in the } \\
\text { active group compared to control group in } \\
\text { the prescribing of medium- and long-acting } \\
\text { BZDs and total BZDs but not so for } \\
\text { antipsychotic drugs. }\end{array}$ \\
\hline $\begin{array}{l}\text { Pimlott et } \\
\text { al., } 2003\end{array}$ & $\begin{array}{l}\text { Educating } \\
\text { physicians to } \\
\text { reduce } \\
\text { benzodiazepine } \\
\text { use } \\
\text { by elderly } \\
\text { patients: a } \\
\text { randomized } \\
\text { controlled trial }\end{array}$ & $\begin{array}{l}\text { Cana } \\
\text { da }\end{array}$ & RCT & $\begin{array}{l}\text { general } \\
\text { practices }\end{array}$ & $\begin{array}{l}12 \\
\text { months }\end{array}$ & 374 & $\begin{array}{l}\text { general practitioners, } \mathrm{M}= \\
50.6 / 50.7 \text { years, not } \\
\text { reported } \\
\text { intervention group (168) } \\
\text { control group (206) }\end{array}$ & $\begin{array}{l}\text { feedback packages were mailed that } \\
\text { presented bar graphs comparing the } \\
\text { prescriber with his or her peers \& a } \\
\text { hypothetical "best practice" } \\
\text { supported by evidence-based } \\
\text { educational material }\end{array}$ & $\begin{array}{l}\text { essential } \\
\text { characteristics } \\
\text { of the clinician }\end{array}$ & $\begin{array}{l}\text { Although the proportion of long-acting } \\
\text { benzodiazepine prescriptions decreased by } \\
0.7 \% \text { in the intervention group between the } \\
\text { baseline period and the end of the } \\
\text { intervention period (from } 20.3 \% \text {, or a mean } \\
\text { of } 29.5 \text { prescriptions, to } 19.6 \% \text {, or a mean } \\
\text { of } 27.7 \text { prescriptions) and increased by } \\
1.1 \% \text { in the control group (from } 19.8 \% \text {, or } \\
\text { a mean of } 26.4 \text { prescriptions, to } 20.9 \% \text {, or a } \\
\text { mean of } 27.7 \text { prescriptions) }(p=0.036 \text { ), this } \\
\text { difference was not clinically significant. }\end{array}$ \\
\hline $\begin{array}{l}\text { Pit et al., } \\
2007\end{array}$ & $\begin{array}{l}\text { A Quality Use of } \\
\text { Medicines } \\
\text { program for } \\
\text { general } \\
\text { practitioners and } \\
\text { older people: a } \\
\text { cluster } \\
\text { randomized } \\
\text { controlled trial }\end{array}$ & $\begin{array}{l}\text { Aust } \\
\text { ralia }\end{array}$ & RCT & $\begin{array}{l}\text { general } \\
\text { practices }\end{array}$ & $\begin{array}{l}12 \\
\text { months }\end{array}$ & $\begin{array}{l}20 \\
\text { physician } \\
\mathrm{s}\end{array}$ & $\begin{array}{l}\mathrm{n}=20 \quad \text { general } \\
\text { practitioners in } 16 \\
\text { practices with } \mathrm{n}=849 \\
\text { patients, older than } 65 \\
\text { years } \\
\text { intervention group (397) } \\
\text { control group (352) }\end{array}$ & $\begin{array}{l}\text { educational sessions by pharmacists } \\
\text { explaining how to conduct } \\
\text { medication reviews with emphasis } \\
\text { on benzodiazepines, accompanied } \\
\text { by written sources of information on } \\
\text { prescribing medication; risk } \\
\text { assessment contained } 31 \text { items } \\
\text { assessing risk factors for medication } \\
\text { misadventure }\end{array}$ & $\begin{array}{l}\text { essential } \\
\text { characteristics } \\
\text { of the clinician }\end{array}$ & $\begin{array}{l}\text { Compared with the control group, } \\
\text { participants in the intervention group had } \\
\text { increased odds of having an improved } \\
\text { medication use composite score (odds ratio } \\
\text { [OR], } \\
1.86 ; 95 \% \text { CI, } 1.21-2.85 \text { ) at 4-month } \\
\text { follow-up but not at } 12 \text { months. }\end{array}$ \\
\hline $\begin{array}{l}\text { Roberts } \\
\text { et al., } \\
2001\end{array}$ & $\begin{array}{l}\text { Outcomes of a } \\
\text { randomized } \\
\text { controlled trial of a } \\
\text { clinical pharmacy } \\
\text { intervention in } 52 \\
\text { nursing homes }\end{array}$ & $\begin{array}{l}\text { Aust } \\
\text { ralia }\end{array}$ & RCT & $\begin{array}{l}\text { nursing } \\
\text { homes }\end{array}$ & $\begin{array}{l}12 \\
\text { months }\end{array}$ & $\begin{array}{l}52 \\
\text { nursing } \\
\text { homes }\end{array}$ & $\begin{array}{l}52 \text { nursing homes with } \\
\mathrm{n}=3.230 \text { patients, not } \\
\text { reported } \\
\text { intervention group of } 13 \\
\text { nursing homes }(905) \\
\text { control group of } 39 \\
\text { nursing homes }(2325)\end{array}$ & $\begin{array}{l}\text { clinical pharmacy service model } \\
\text { based on issues such as drug policy } \\
\& \text { specific resident problems, } \\
\text { together with education \& } \\
\text { medication review and problem- } \\
\text { based educational sessions for } \\
\text { nurses addressing basic geriatric } \\
\text { pharmacology \& some common } \\
\text { problems in long-term care } \\
\text { medication; review by pharmacists } \\
\text { highlighting the potential for adverse } \\
\text { drug effects, ceasing one or more }\end{array}$ & $\begin{array}{l}\text { essential } \\
\text { characteristics } \\
\text { of the clinician }\end{array}$ & $\begin{array}{l}\text { This intervention resulted in a reduction in } \\
\text { drug use with no change in morbidity } \\
\text { indices or survival. } \\
\text { The use of benzodiazepines was } \\
\text { significantly reduced in the intervention } \\
\text { group. } \\
\text { Overall, drug use in the intervention group } \\
\text { was reduced by } 14.8 \% \text { relative to the } \\
\text { controls. }\end{array}$ \\
\hline
\end{tabular}




\begin{tabular}{|c|c|c|c|c|c|c|c|c|c|c|}
\hline & & & & & & & & $\begin{array}{l}\text { drug therapy, non-drug intervention } \\
\& \text { adverse effect \& drug response } \\
\text { monitoring }\end{array}$ & & \\
\hline $\begin{array}{l}\text { Smith et } \\
\text { al. } \\
1998\end{array}$ & $\begin{array}{l}\text { A Randomized } \\
\text { Controlled Trial of } \\
\text { a Drug Use } \\
\text { Review } \\
\text { Intervention for } \\
\text { Sedative Hypnotic } \\
\text { Medications }\end{array}$ & USA & RCT & $\begin{array}{l}\text { Medicaid } \\
\text { recipients } \\
\text { (outpatients } \\
\text { ) }\end{array}$ & 6 months & 189 & $\begin{array}{l}\text { BZDs users, } 55 \text { years and } \\
\text { older, } 61 \%-63 \% \text { women } \\
\text { intervention group (99) } \\
\text { control group (89) }\end{array}$ & $\begin{array}{l}\text { written information consisted of: } \\
\text { a letter describing the drug use \& } \\
\text { education council } \\
\text { guidelines for sedative hypnotic } \\
\text { prescribing; a prescriber-specific } \\
\text { profile about sedative hypnotic } \\
\text { prescribing; a patient profile for each } \\
\text { of the prescribers patients identified } \\
\text { as over utilizers; }\end{array}$ & $\begin{array}{l}\text { essential } \\
\text { characteristics } \\
\text { of the clinician }\end{array}$ & $\begin{array}{l}\text { The intervention achieved a statistically } \\
\text { significant decrease in targeted drug use, } \\
\text { and the amount of reduction is likely to } \\
\text { have decreased the risk of fractures } \\
\text { associated with benzodiazepine use. }\end{array}$ \\
\hline $\begin{array}{l}\text { Smith et } \\
\text { al., } \\
2010\end{array}$ & $\begin{array}{l}\text { An intervention to } \\
\text { improve } \\
\text { benzodiazepine } \\
\text { use - a new } \\
\text { approach }\end{array}$ & $\begin{array}{l}\text { Aust } \\
\text { ralia }\end{array}$ & CT & $\begin{array}{l}\text { general } \\
\text { practices } \\
\text { (outpatients } \\
\text { ) }\end{array}$ & 6 months & $\begin{array}{l}429 \\
\text { physician } \\
\text { s }\end{array}$ & $\begin{array}{l}429 \text { physicians } \\
\text { intervention group (not } \\
\text { reported) } \\
\text { control group (not } \\
\text { reported) }\end{array}$ & $\begin{array}{l}\text { information emails consisted of } \\
\text { educational facts relating to } \\
\text { benzodiazepines, } \\
\text { including } \\
\text { information on common side effects, } \\
\text { indications, precautions \& } \\
\text { recommendations regarding } \\
\text { prescribing as well as characteristics } \\
\text { \& alternative non-drug techniques; } \\
\text { the website contained links to } \\
\text { Australian Department of Health \& } \\
\text { Ageing websites which provided } \\
\text { consumer information on medicines } \\
\text { including sleeping tablets }\end{array}$ & $\begin{array}{l}\text { essential } \\
\text { characteristics } \\
\text { of the clinician }\end{array}$ & $\begin{array}{l}\text { A significantly smaller number of aged care } \\
\text { residents were on benzodiazepines for } 6 \\
\text { months or more }(\mathrm{P}<0.05) \text { after the } \\
\text { intervention compared with before. }\end{array}$ \\
\hline
\end{tabular}




\section{Table 3 (on next page)}

Description of included studies: patients and health care professionals 
Table 1: description of included studies- interventions regarding patients and health care professionals

\begin{tabular}{|c|c|c|c|c|c|c|c|c|c|c|}
\hline reference & title & $\begin{array}{l}\text { locat } \\
\text { ion }\end{array}$ & $\begin{array}{l}\text { desig } \\
\mathrm{n}\end{array}$ & setting & duration & $\begin{array}{l}\text { sample } \\
\text { total n }\end{array}$ & $\begin{array}{l}\text { sample } \\
\text { definition, mean age, } \\
\text { sex distribution, } \\
\text { groups }\end{array}$ & intervention & $\begin{array}{l}\text { dimension of } \\
\text { patient- } \\
\text { centered-care } \\
\text { model } \\
\end{array}$ & findings \\
\hline $\begin{array}{l}\text { Patterson } \\
\text { et al., } \\
2010 \\
(56)\end{array}$ & $\begin{array}{l}\text { An Evaluation of } \\
\text { an Adapted U.S. } \\
\text { Model of } \\
\text { Pharmaceutical } \\
\text { Care to Improve } \\
\text { Psychoactive } \\
\text { Prescribing for } \\
\text { Nursing Home } \\
\text { Residents } \\
\text { in Northern } \\
\text { Ireland } \\
\text { (Fleetwood } \\
\text { Northern Ireland } \\
\text { Study) } \\
\end{array}$ & $\begin{array}{l}\text { Irela } \\
\text { nd }\end{array}$ & RCT & $\begin{array}{l}\text { nursing } \\
\text { homes }\end{array}$ & $\begin{array}{l}12 \\
\text { months }\end{array}$ & $\begin{array}{l}22 \text { nursing } \\
\text { homes }\end{array}$ & $\begin{array}{l}22 \text { nursing homes with } \\
\mathrm{n}=334 \text { residents, } \\
\mathrm{M}=82.7,73 \% \text { female } \\
\text { intervention group } \\
\text { (173) } \\
\text { control group (161) }\end{array}$ & $\begin{array}{l}12 \text { monthly visits from pharmacist } \\
\text { to review prescription records of } \\
\text { nursing home residents; } \\
\text { collaboration of pharmacists with } \\
\text { prescribers and patients to improve } \\
\text { prescription patterns; } \\
\text { pharmacist's visits assessed the } \\
\text { pharmaceutical care needs of each } \\
\text { resident to identify potential \& } \\
\text { actual medication-related problems } \\
\& \text { reviewed the residents' } \\
\text { medication with the aim of } \\
\text { optimizing psychoactive } \\
\text { prescription }\end{array}$ & $\begin{array}{l}\text { essential } \\
\text { characteristics } \\
\text { of the clinician, } \\
\text { clinician- } \\
\text { patient- } \\
\text { communication } \\
\text { and patient } \\
\text { information }\end{array}$ & $\begin{array}{l}\text { The proportion of residents taking } \\
\text { inappropriate psychoactive medications at } \\
12 \text { months in the intervention homes } \\
(25 / 128,19.5 \%) \text { was much lower than in } \\
\text { the control homes }(62 / 124,50.0 \%) \text { (odds } \\
\text { ratio } 50.26,95 \% \text { confidence interval } \\
50.14-0.49) \text { after adjustment for clustering } \\
\text { within homes. }\end{array}$ \\
\hline $\begin{array}{l}\text { Westbury } \\
\text { et al. } \\
2010 \\
(57) ;\end{array}$ & $\begin{array}{l}\text { An effective } \\
\text { approach to } \\
\text { decrease } \\
\text { antipsychotic and } \\
\text { benzodiazepine } \\
\text { use in nursing } \\
\text { homes: the } \\
\text { RedUSe project }\end{array}$ & $\begin{array}{l}\text { Aust } \\
\text { ralia }\end{array}$ & $\mathrm{CT}$ & $\begin{array}{l}\text { nursing } \\
\text { homes }\end{array}$ & 6 months & $\begin{array}{l}25 \text { nursing } \\
\text { homes }\end{array}$ & $\begin{array}{l}25 \text { nursing homes with } \\
\mathrm{n}=1591 \text { residents, not } \\
\text { reported } \\
\text { intervention group } 13 \\
\text { nursing homes } \\
\text { control group } \mathrm{n}=12 \\
\text { nursing homes }\end{array}$ & $\begin{array}{l}\text { consciousness raising } \\
\text { two drug use evaluation (DUE) } \\
\text { cycles educational sessions } \\
\text { promotional materials (newsletters, } \\
\text { pamphlets, posters) } \\
\text { and educational sessions \& } \\
\text { materials focused on informing } \\
\text { health professionals \& participants } \\
\text { about risks \& modest benefits } \\
\text { associated with antipsychotic } \\
\text { medications for dementia \& } \\
\text { benzodiazepines for sleep } \\
\text { disturbance \& anxiety management } \\
\text { in elderly people }\end{array}$ & $\begin{array}{l}\text { essential } \\
\text { characteristics } \\
\text { of the clinician, } \\
\text { clinician-patient } \\
\text { communication } \\
\text { and patient in- } \\
\text { formation }\end{array}$ & $\begin{array}{l}\text { Over the six-month trial, there was a } \\
\text { significant reduction in the percentage of } \\
\text { intervention home residents regularly } \\
\text { taking benzodiazepines ( } 31.8 \% \text { to } 26.9 \% \text {, } \\
\text { p }<0.005 \text { ). For residents taking } \\
\text { benzodiazepines at baseline, there were } \\
\text { significantly more dose reductions/ } \\
\text { cessations in intervention homes than in } \\
\text { control homes (benzodiazepines: } 39.6 \% \\
\text { vs. } 17.6 \%, \mathrm{p}<0.0001 \text { ). }\end{array}$ \\
\hline
\end{tabular}




\title{
Table 4(on next page)
}

\author{
Risk of bias
}


1 Table 1: methodological quality of the included studies $(n=20)$ - assessment of risk of bias

\begin{tabular}{|c|c|c|c|c|c|c|}
\hline reference & $\begin{array}{l}\text { Random } \\
\text { sequence } \\
\text { generation }\end{array}$ & $\begin{array}{l}\text { Allocation } \\
\text { concealment }\end{array}$ & $\begin{array}{l}\text { Blinding of } \\
\text { participants and } \\
\text { personnel }\end{array}$ & $\begin{array}{l}\text { Blinding of } \\
\text { outcome } \\
\text { assessment }\end{array}$ & $\begin{array}{l}\text { Incomplete } \\
\text { outcome data }\end{array}$ & $\begin{array}{l}\text { Selective } \\
\text { reporting }\end{array}$ \\
\hline \multicolumn{7}{|c|}{ Interventions for patients } \\
\hline $\begin{array}{ll}\text { Bashir et } & \text { et } \\
\text { al., } 1994\end{array}$ & N.R. & $\mathrm{H}$ & $\mathrm{H}$ & $\mathrm{U}$ & $\mathrm{L}$ & $\mathrm{U}$ \\
\hline $\begin{array}{l}\text { Cormack et } \\
\text { al., } 1994\end{array}$ & N.R. & $\mathrm{L}$ & $\mathrm{H}$ & $\mathrm{U}$ & $\mathrm{U}$ & $\mathrm{U}$ \\
\hline $\begin{array}{l}\text { Gorgels et } \\
\text { al., 2005 }\end{array}$ & N.R. & $\mathrm{H}$ & $\mathrm{H}$ & $\mathrm{U}$ & $\mathrm{L}$ & $\mathrm{U}$ \\
\hline $\begin{array}{l}\text { Tannen- } \\
\text { baum et al., } \\
2014\end{array}$ & $\mathrm{~L}$ & $\mathrm{~L}$ & $\mathrm{~L}$ & $\mathrm{~L}$ & $\mathrm{~L}$ & $\mathrm{~L}$ \\
\hline $\begin{array}{l}\text { Ten Wolde } \\
\text { et al., } 2008\end{array}$ & $\mathrm{~L}$ & $\mathrm{~L}$ & $\mathrm{U}$ & $\mathrm{U}$ & $\mathrm{H}$ & $\mathrm{U}$ \\
\hline $\begin{array}{ll}\text { Stewart } & \text { et } \\
\text { al., } 2007 & \end{array}$ & N.R. & $\mathrm{H}$ & $\mathrm{H}$ & $\mathrm{L}$ & $\mathrm{U}$ & $\mathrm{U}$ \\
\hline $\begin{array}{l}\text { Heather et } \\
\text { al., 2004 }\end{array}$ & $\mathrm{L}$ & $\mathrm{U}$ & $\mathrm{H}$ & $\mathrm{L}$ & $\mathrm{H}$ & $\mathrm{U}$ \\
\hline $\begin{array}{l}\text { Vicens et } \\
\text { al., 2006 }\end{array}$ & $\mathrm{L}$ & $\mathrm{L}$ & $\mathrm{H}$ & $\mathrm{U}$ & $\mathrm{L}$ & $\mathrm{U}$ \\
\hline $\begin{array}{l}\text { Vicens et } \\
\text { al., 2014 }\end{array}$ & $\mathrm{L}$ & $\mathrm{L}$ & $\mathrm{H}$ & $\mathrm{L}$ & $\mathrm{L}$ & $\mathrm{U}$ \\
\hline \multicolumn{7}{|c|}{ Interventions for HCPs } \\
\hline $\begin{array}{l}\text { Avorn et } \\
\text { al., } 1992\end{array}$ & $\mathrm{~L}$ & $\mathrm{U}$ & $\mathrm{U}$ & $\mathrm{U}$ & $\mathrm{H}$ & $\mathrm{U}$ \\
\hline $\begin{array}{l}\text { Batty et al., } \\
2001\end{array}$ & $\mathrm{~L}$ & $\mathrm{U}$ & $\mathrm{H}$ & $\mathrm{H}$ & $\mathrm{U}$ & $\mathrm{U}$ \\
\hline $\begin{array}{ll}\text { Berings } & \text { et } \\
\text { al.,1994 } & \\
\end{array}$ & $\mathrm{L}$ & $\mathrm{U}$ & $\mathrm{H}$ & $\mathrm{U}$ & $\mathrm{U}$ & $\mathrm{U}$ \\
\hline $\begin{array}{ll}\text { Midlöv } & \text { et } \\
\text { al., } 2006\end{array}$ & $\mathrm{~L}$ & $\mathrm{U}$ & $\mathrm{H}$ & $\mathrm{U}$ & $\mathrm{U}$ & $\mathrm{U}$ \\
\hline $\begin{array}{l}\text { Pimlott et } \\
\text { al., 2003 }\end{array}$ & $\mathrm{L}$ & $\mathrm{U}$ & $\mathrm{L}$ & $\mathrm{L}$ & $\mathrm{U}$ & $\mathrm{U}$ \\
\hline $\begin{array}{l}\text { Pit et al., } \\
2007\end{array}$ & $\mathrm{~L}$ & $\mathrm{U}$ & $\mathrm{H}$ & $\mathrm{L}$ & $\mathrm{H}$ & $\mathrm{U}$ \\
\hline $\begin{array}{l}\text { Roberts et } \\
\text { al., 2001 }\end{array}$ & $\mathrm{L}$ & $\mathrm{U}$ & $\mathrm{H}$ & $\mathrm{U}$ & $\mathrm{H}$ & $\mathrm{U}$ \\
\hline $\begin{array}{l}\text { Smith et al. } \\
1998\end{array}$ & $\mathrm{~L}$ & $\mathrm{U}$ & $\mathrm{H}$ & $\mathrm{U}$ & $\mathrm{H}$ & $\mathrm{U}$ \\
\hline $\begin{array}{l}\text { Smith et al., } \\
2010\end{array}$ & N.R. & $\mathrm{U}$ & $\mathrm{H}$ & $\mathrm{H}$ & $\mathrm{H}$ & $\mathrm{U}$ \\
\hline \multicolumn{7}{|c|}{ Interventions for patients and $\mathrm{HCPs}$} \\
\hline $\begin{array}{l}\text { Patterson et } \\
\text { al., } 2010\end{array}$ & $\mathrm{~L}$ & $\mathrm{~L}$ & $\mathrm{H}$ & $\mathrm{U}$ & $\mathrm{L}$ & $\mathrm{U}$ \\
\hline $\begin{array}{l}\text { Westbury et } \\
\text { al. } 2010\end{array}$ & N.R. & $\mathrm{H}$ & $\mathrm{H}$ & $\mathrm{U}$ & $\mathrm{U}$ & $\mathrm{U}$ \\
\hline
\end{tabular}

Rating: L- low risk of bias; H- high risk of bias; U- unclear risk of bias; N.R.- no relevance (controlled study design) 